\title{
Working
}

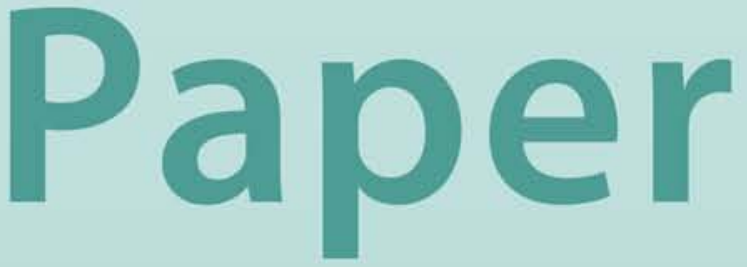




\title{
Should Advanced Countries Adopt a Fiscal Responsibility Law?
}

\author{
Ian Lienert
}




\title{
IMF Working Paper
}

Fiscal Affairs Department

\section{Should Advanced Countries Adopt a Fiscal Responsibility Law?}

\author{
Prepared by Ian Lienert ${ }^{1}$ \\ Authorized for distribution by Michel Lazare
}

November 2010

\begin{abstract}
This Working Paper should not be reported as representing the views of the IMF. The views expressed in this Working Paper are those of the author and do not necessarily represent those of the IMF or IMF policy. Working Papers describe research by the author and are published to elicit further debate.

Fiscal Responsibility Laws (FRLs) appear to be more popular in middle-income countries than advanced countries, even though their success is limited. The reasons why few advanced countries have a FRL include: the existing legal framework for the budget system is adequate; supranational rules and political agreements in EU countries; failed attempts to include quantitative fiscal rules in laws; lack of consensus or interest in attaining the goals of FRL-type legislation; and lack of need for a law to regulate fiscal transparency, accountability and macro-fiscal stabilization. Without commitment to fiscal discipline, adoption of a FRL may not contribute to attaining fiscal consolidation goals.

JEL Classification Numbers:H30, H50, H60, H61, H62, H63, H68, K00, K39
\end{abstract}

Keywords: fiscal responsibility, accountability, fiscal transparency, law, budget

Author's E-Mail Address: lienert.ian@gmail.com

\footnotetext{
${ }^{1}$ This paper benefitted from substantive comments made at a Fiscal Affairs Department seminar held on June 23, 2010, especially by G. Blondy, M. Cangiano, P. Khemani, M. Lazare, M. Pessoa, and H. van Eden (Fiscal Affairs Department). Helpful comments were later received from James Daniel and other IMF colleagues of the IMF's European and Western Hemisphere Departments, advisors in Executive Directors' offices and H. Tollini (budget advisor to Brazil's Congress). All remaining errors are the author's.
} 
I. Introduction

II. What Are the Objectives and Coverage of a Fiscal Responsibility Law?

A. What is a Fiscal Responsibility Law (FRL)? ........................................................

B. Accountability to Whom? ................................................................................

C. Transparency of Fiscal Policy Intentions ................................................................

D. Ex Post Accountability of the Government to the Legislature and Public ................. 8

E. Fiscal Stability and Public Debt Sustainability ........................................................

F. Comprehensiveness of the Fiscal Framework and Institutions to Implement It ......11

III. Assessment of Country Experience with Fiscal Responsibility Laws.................................11

A. Country Experience...........................................................................................11

B. Successes and Failures of FRLs ……………………………………………....

IV. Why Most OECD and Advanced Countries Have Not Adopted a FRL...............................16

A. Adequacy of Existing Legal Framework for Budget System ...................................16

B. Law Perceived to be Less Necessary or Unnecessary for FRL................................19

C. Independent Institutions Contribute to the Accountability of Government..............20

D. Supranational Fiscal Rules and Fiscal Stability Laws in EU countries ....................22

E. Role Played by Coalition Agreements .................................................................24

F. The Limited Success of Including Quantitative Fiscal Rules in Law ……………....25

G. The Political Difficulty of Adopting FRLs ............................................................27

H. Strong Legislatures Reject Executive Dominance in Budget Matters ......................28

I. Freedom of Information Laws Set Tone for Transparency ………………………......

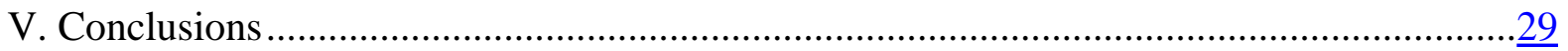

Bibliography .................................................................................................................

Tables

1. Fiscal Reponsibility Laws in Emerging and Developing Countries.....................................14

2 Coalition Agreements in Selected European Countries.........................................................

Figures

1. Fiscal Responsibility Laws in OECD Countries................................................................

Boxes

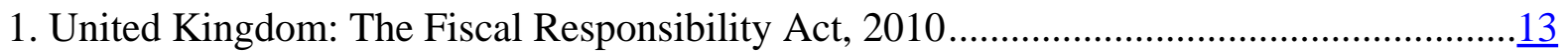

2. New Zealand: Strengths and Weakness of the 1994 Fiscal Responsibility Act .....................15

3. Constitutional Constraints on Budget Management …………………………..................

4. Iceland: Government Financial Reporting Act, No. 88/1997 ………………………….......19

5. Roles of Independent Fiscal Councils............................................................................21

6. Content of Stability and Convergence Programs of EU countries ........................................22 
7. Austria and Italy: National and Domestic Stability Pacts..............................................24

8. United States: FRL-type legislation in the 1980s and 1990s...........................................

\section{Appendixes}

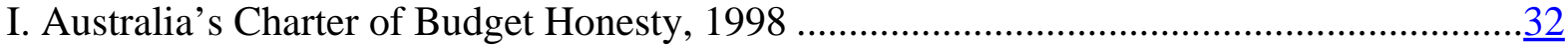

II. Japan: Experiences with Legislated Fiscal Rules.......................................................

III. Experiences of FRLs in India, Pakistan and Sri Lanka .............................................

IV. Germany: Legal Basis for Budget System..........................................................

V. Fiscal Stability Laws in Spain and Portugal ..............................................................

VI. Brazil—Features of Legal Framework, including the FRL ...........................................39 


\section{INTRODUCTION}

The objective of being "fiscally responsible" is admirable. It invokes the concepts of accountability and transparency: the government is responsible before parliament and the public for providing clear information on past fiscal outcomes, expected fiscal developments, and the policies proposed to deal with any fiscal imbalances and deviations from an agreed medium-term fiscal strategy. To attain fiscal stability goals, the government and the legislature need to be responsible by adopting sound fiscal policies and managing the annual budget in a way that contributes to economic development and a sustainable debt situation.

Can a country impose fiscal responsibility by law? Since a number of countries have adopted a fiscal responsibility law (FRL), the answer to this question appears to be “yes". Around 40 percent of a sample of emerging countries have, at some time in the past, embedded a fiscal rule in FRL-type legislation. The corresponding percentage for advanced countries is only 20 percent. $^{2}$ In fact, only two advanced countries ${ }^{3}$ currently have a FRL in operation.

The reasons why a country adopted a FRL or a FRL-type law have been published by Ministries of Finances (MoFs), academic researchers, parliaments, or think-tanks. However, there is a dearth of cross-country studies on FRLs for advanced countries, mainly because there are very few such laws. In cross-country studies of FRLs, South American countries dominate the sample (e.g., Oliva, 2001; Webb, 2004). After examining the characteristics, and impact of FRLs on fiscal outcomes, Corbacho and Schwartz (2007) conclude that FRLs cannot buy credibility or substitute for commitment to prudent fiscal policy.

This paper explores why so few advanced countries have adopted a FRL Possible reasons include: advanced countries are more mature than emerging countries with respect to the aims of FRLs; they may be more resistant to, or see less need to, use law to attain the objectives of FRLs; advanced countries are not under pressure from the international community to adopt FRLs (in emerging and developing countries, FRLs have been advocated by multilateral organizations ${ }^{4}$ as a way of addressing fiscal weaknesses). This paper is laid out as follows. Part II defines a FRL narrowly and discusses the main objectivs of FRLs and FRL-type laws. Part III examines country experiences with FRLs, in both advanced and emerging economies, and briefly assesses them. Before concluding,

\footnotetext{
${ }^{2}$ See the second panel of Figure 4, IMF (2009).

${ }^{3}$ The two countries are Australia and the United Kingdom. In this paper, there are 33 advanced countries corresponding to the grouping used by the IMF in its World Economic Outlook publication (all other countries are classified as “emerging” or “developing”). The advanced country grouping includes 26 of the 30 OECD member countries (it excludes Hungary, Mexico, Poland and Turkey). Also included are: Cyprus, Hong Kong, Israel, Malta, Singapore, Slovenia and Taiwan.

${ }^{4}$ Examples are: (1) Tanzania, 2001: the IMF proposed a FRL (see footnote 19 of Kim and Saito, 2009);

(2) Maldives: the Asian Development Bank requires presentation of a draft FRL to parliament in 2011.
} 
Part IV enumerates the various reasons why advanced countries have not promulgated FRLs. The six appendices review FRLs and FRL-related laws in selected countries.

\section{What ARE THE ObJectives AND COVERAgE OF A Fiscal RESPONSIBILITy LAW?}

\section{A. What is a Fiscal Responsibility Law (FRL)?}

Laws relating to the budget system elaborate on various principles, including budget authority, common pooling of revenues, the specificity of spending, budget unity and performance (Lienert and Fainboim, 2010). Budget systems laws are very diverse across countries (Lienert and Jung, 2004). FRLs are subset of the wider set of budget-related laws that encompass all conceivable budget principles.

A law with "fiscal responsibility" in its title clearly qualifies as a FRL. Can a budget-related law, which does not contain the words "fiscal responsability" in its title, also qualify as a FRL? In practice, some FRLs have denser coverage than others. Also, some countries have adopted Fiscal Stability Laws. Are these also FRLs? A clear definition of a FRL is needed.

Definition. A "Fiscal Responsibility Law" is a limited-scope law that elaborates on the rules and procedures relating to three budget principles: accountability, transparency and stability. For the purpose of this paper, a distinction is made between a FRL, which satisfies four specific accountability/transparency criteria, and FRL-type laws, which may include a number of provisions relating to fiscal transparency, accountability and stability, but not all four components of a FRL deemed to be "essential”.

There are no clear criteria for deciding on the obligatory and optional provisions of a FRL. The chosen four essential features, discussed in the next subsections, specify desirable minimum obligatory requirements for responsible fiscal policy management. The following requirements are considered the core components of "fiscal responsibility":

- $\quad$ Specification of the medium-term path of fiscal aggregates.

- $\quad$ Description of the medium-term and annual budget strategy for attaining the chosen fiscal objectives.

- $\quad$ Regular publication of reports (at least twice a year) on the attainment of fiscal objectives or targets.

- $\quad$ Audited annual financial statements that assure the integrity of fiscal information.

In practice, FRLs include more that these four features - FRLs are replete with the "optional" features. When a limited-scope budget-related law includes several "optional" features, but not all four obligatory provisions, it will be considered as a FRL-type law in this paper. 


\section{B. Accountability to Whom?}

There are certain aspects of accountability or responsibility that do not qualify as essential features of a FRL. Accountability of the executive branch to the legislative branch (or "parliament”) requires the government to be transparent for both its fiscal policy intentions and its ex post fiscal performance. This is an essential aspect of accountablity to be covered in a FRL. It could be categorized as transparency of fiscal policy intentions.

In contrast, accountability within the executive (or "government") is not considered to be a necessary component of a FRL. In performance based budget (PBB) systems, individual budget managers (agents) are reponsible to the political authorities of the government, typically the Cabinet of ministers (principals). Budget managers are accountable to achieve outputs and results in specific budgets. This usually takes place in budget systems with devolved fiscal management, under which annual performance reports are prepared by each government ministry and automous agency funded by the national budget. Laws that relate to PBB systems are not considered to be a component of a FRL-type law.

Two examples illustrate. The USA’s Government Performance and Results Act, 1990, is a law dedicated to requiring U.S. federal agencies to budget for results. New Zealand's State Sector Act, 1988, established contractual relationships for “chief executives”, who are responsible for the delivery of outputs to government Ministers. This law is a central element of New Zealand's well-know system of “responsible” fiscal management (Schick, 1996). However, in neither of these two cases are these laws considered FRL-type laws, since their focus is on a PBB system and accountabilities within the (federal) government.

Summarizing, laws that elaborate on individual responsibility for budget program management are not considered to be FRL-type laws. In contrast, laws that elaborate on the government's collective responsibility to parliament for macro-fiscal management are FRLs. Such laws address primarily the transparency of a government's fiscal policy intentions and outcomes. Unlike individual program management, where the government is the "principal”, under an FRL, the government is the "agent" and parliament is the "principal”. It is parliament, not the government, that decides on the content of the FRL.

\section{Transparency of Fiscal Policy Intentions ${ }^{5}$}

When proposing to parliament a new draft annual budget, a government should be explicit about its fiscal policy intentions. The following obligatory and optional features of a FRL ${ }^{6}$ would be included in annual budget documents.

\footnotetext{
${ }^{5}$ For a full discussion on fiscal transparency, see IMF (2007).

${ }^{6}$ For an example of the possible content of the transparency requirements of a FRL, see Australia's Charter of Budget Honesty, summarized in Appendix I.
} 


\section{Obligatory components of a FRL}

- A medium-term fiscal policy strategy. The FRL would require the government's fiscal strategy and policy intentions to be published. Macroeconomic and fiscal projections, including the main technical and policy assumptions, would be prepared for a period of at least two years after the upcoming new fiscal year. The medium term budget framework (MTBF) would show quantified objectives and targets for the fiscal balance, aggregate revenue and expenditure, and government debt. It would also spell out the broad fiscal policy priorities of the government.

- An annual budget policy strategy. The FRL would require the government to explain how the proposed budget for the upcoming fiscal year helps achieve mediumterm fiscal policy objectives and targets, along with the fiscal policy measures envisaged to achieve the annual and medium-term fiscal targets. The annual budget documents would elicit the reasons why the MTBF is changing-factors include the impact of external events on the macroeconomic framework or specific policy changes. The FRL would require the government to explain why the government is deviating from the previously announced fiscal strategy, if this is the case.

\section{Optional components of a FRL}

- $\quad$ New versus existing policies. An FRL may require quantifying the impact of new tax or spending policies that the government intends to take to meet its medium-term fiscal targets. These would preferably be identified relative to baseline medium-term projections (sometimes called "forward estimates") based on unchanged policies.

- $\quad$ Fiscal risks. Such risks arise from: unforeseen macroeconomic developments (external shocks); policy risks; debt risks, including those from contingent liabilities; the operations of subnational governments, public-private partnerships and stateowned enterprises; natural disasters; and fluctuations in the value of government acquired assets (see Cebotari, 2008, Cebotari et al., 2009, Everaert et al, 2009).

- Tax expenditures. The growth of tax expenditures - deviations from established tax norms that are intended to benefit a specific activity or class of taxpayer-can be a source of circumventing constraints on total spending. A FRL may require tax expenditures to be identified and quantified as part of annual budget documentation.

- Scenarios indicating how fiscal balances in the long term would change under various assumptions. In countries where ageing populations present a potential threat to long-term fiscal sustainability (e.g., under unchanged policies for publiclysupported pension schemes), the FRL may require discussion of policy options and scenarii assessing the impact on government expenditures in the longer term of changing demographics or other factors such as climate change or health care costs. 


\section{Ex Post Accountability of the Government to the Legislature and Public}

The provision of regular, timely and high-quality fiscal reports are essential components of ex post accountability.

\section{Obligatory components of FRL-type legislation}

- A mid-year formal review of budget outcomes and/or a pre-budget report. The mid-year review provides an opportunity for the public to be provided with audited accounts and fiscal outcomes for the previous fiscal year, the estimated fiscal developments in the first six months of the current fiscal year, and revised fiscal prospects for the current year and medium-term (if needed, a proposal for a supplementary annual budget law for the current year would be presented). The prebudget report focuses on the broad orientiations of the annual budget for the upcoming fiscal year, consistent with the MTBF's fiscal targets. The aim of the review is to involve parliament in discussing any revisions to the macro-fiscal position 5-7 months before a new fiscal year, separate from the parliamentary debate on the detailed annual budget $0-3$ months before the beginning of a new fiscal year.

- Annual financial statements. Under cash-based accounting, the FRL would require presentation of financial statements that indicate the revenue and expenditure outturns of the previous fiscal year, comparing them with the annual budget voted by the legislature. When accrual accounting is required (or adopted voluntarily), a balance sheet of government assets and liabilities would be part of the annual financial statements. The statements would relate to the "whole of government" (coverage of accounts is discussed in subsection $\mathrm{F}$ below).

\section{Optional components of FRL-type legislation}

- In-year fiscal outcome reports, with a comparison with the budget estimates. The FRL could indicate the frequency, e.g., monthly/quarterly reports, and publication format, e.g., on the MOF website.

- Long-term fiscal projections and other special-purpose reports. The FRL may require additional reports, including reports on long-term fiscal developments, ${ }^{7}$ the fiscal outlook prior to general elections, or how the government has followed up on the external auditor's annual report.

\section{E. Fiscal Stability and Public Debt Sustainability}

A FRL must require the government to make a statement concerning the key objectives and policies for total revenues and expenditures, the overall (or primary) fiscal balance, and

\footnotetext{
${ }^{7}$ Although a number of OECD countries prepare long-term projections (Anderson and Sheppard, 2009), only Australia, Iceland and New Zealand impose this as a legal requirment in their FRLs or FRL-type legislation.
} 
public debt. The time period for which these objectives apply are at least short-term (year by year objectives or targets) and medium-term (either a specific target to attain within 3-5 years or "over the cycle"). Period longer than five years are optional. The FRL does not need to include rigid numeric targets (unchangeable "anchors" for fiscal policy), but rather a clear statement of medium-term fiscal objectives and policies. The following elements of fiscal stability and sustainabiltiy are considered optional:

\section{Optional components of FRL-type legislation}

- $\quad$ Numerical fiscal rules. i.e., quantified "permanent" constraints on fiscal policy. ${ }^{8}$ Numerical targets can be established for debt, deficits, total revenue, total expenditure or specific spending categories. They can be defined in various ways (perhaps in secondary legislation) and expressed either as a percentage of GDP, in local currency units (e.g., for debt or the fiscal deficit) or a growth rate (e.g., spending).

- $\quad$ Revenue targets. A FRL may require reasonable stability in the revenue/GDP ratio, tax rates or tax bases. A FRL may require the government (and parliament) to pursue policies that are consistent with a reasonable degree of predictability about the level and stability of tax rates and bases in future years. In countries endowed with natural resources whose prices and/or volumes fluctuate considerably, the underlying medium-term trends in revenue aggregates (and, similarly for deficits and/or spending) can be adjusted for the impact of cyclical fluctuations. A FRL-type law in an oil producing country may require the establishment of targets for the non-oil fiscal balance, not the overall fiscal balance. ${ }^{9}$

- Targets for debt sustainability. A FRL may include quantitative or qualitative targets for public debt (e.g., "reduce debt to 60 percent of GDP within x years" or "reduce debt to a prudent level" $\left.{ }^{10}\right)$. In countries where government-guaranteed debt is

\footnotetext{
${ }^{8}$ See Kopits and Symansky (1998). The design, effects and experiences with fiscal rules are discussed extensively, including in Anderson and Minarik (2006), Ayuso-i-Casals et al (2006), Debrun and Kumar (2007), Debrun et al (2008), Deroose and Wierts (2006), EC (2006a), IMF (2009), Gleich (2003); Hallerberg et al (2004); Kopits (2001, 2004); Schick (2003); Schuknecht (2004); von Hagen (2005), and Yläoutinen (2004).

${ }^{9}$ Baunsgaard (2003) argues that targeting the non-oil primary deficit (i.e., the non-oil deficit excluding debt interest payments) is conceptually superior because it decouples the budget from all sources of oil revenue volatility. However, when Mexico (in 2006) and Nigeria (in 2007) adopted FRLs, their laws do not target the non-oil deficit. Mexico's FRL, which excludes important off-budget operations, subnational governments, and development banks, uses a standard definition of deficit and includes an oil price rule that gives much weight to short-term oil futures prices. As a result, spending can grow procyclically with rising oil prices. Nigeria's FRL included a fiscal rule on total expenditure (which cannot exceed total estimated revenues and a deficit of 3 percent of GDP), estimated oil revenues are based on a reference commodity price determined by the President and approved by the National Assembly. A modified golden rule is also included in Nigeria's FRL.

${ }^{10}$ Poland, which does not have a FRL, is an example of the quantitative approach. Prior to its EU membership, a constitutional amendment introduced a debt rule (60 percent of GDP), in line with the EU's Maastricht Treaty debt criterion. Australia's Charter of Budget Honesty, 1998, is an example of the non-numerical approach.
} 
important, the FRL may impose requirements or limits on government guarantees, since lack of control of these contingent liabilities area may compromise fiscal sustainability objectives.

- $\quad$ Balance sheet stability. Some countries focus attention on net debt: gross debt minus government financial assets. ${ }^{11}$ If integrated asset-liability managemnet (ALM) is practised, the FRL may require the government to set objectives for net worth. ${ }^{12}$ In countries with natural resources and large financial assets, a special law may be adopted to manage surpluses and revenues. Unless such laws also contain transparency and accountability requirements, they are not considered to be a FRL. ${ }^{13}$

\section{Ensuring Parliament is also responsible for macro-fiscal stability}

A responsible parliament is necessary to ensure that the above aspects of a FRL are respected during budget approval processes. Fiscal rules, if incorporated in a FRL, could be ignored by parliament if it avails itself to the FRL's exception (or "escape") clauses to circumvent the intent of the legislation. In this context, about half of the OECD countries' parliaments have unlimited powers to amend a government's draft budget (OECD, 2007). Such powers could potentially derail a government's proposed fiscal consolidation plan for fiscal deficits and debt. Budget amendment provisions are usually in a law other than the FRL and there may not be any legal provisions for sanctioning parliament should it decide to use its budget amendment powers, even if a FRL required responsible budget management by parliament.

The risk of irresponsibility by the legislature is minimized when parliament adopts binding provisions that require it to first approve the broad aggregates of the budget: total revenues, total expenditures; the fiscal balance; and the means of financing any deficit, notably by increasing debt. At a second stage, parliament approves the detailed estimates of expenditure, vote by vote. A two-stage parliamentary adoption procedure could be included amongst optional features of a FRL. However, in practice, it is more likely to be included as part of a separate law or in parliament's internal regulations ("rules” or "standing orders”).

\footnotetext{
${ }^{11}$ During 1998-2008, the United Kingdom's “sustainable investment rule” required the government to ensure that net debt was maintained at less than 40 percent over the cycle. Canada, which has considerable financial assets, also focuses on net debt in fiscal policy discussions (see Chart 4.1.1 of Canada, 2010)

${ }^{12}$ Net worth requires full accrual accounting, which only one third of OECD countries have adopted (OECD, 2007). Net worth is infrequently used as an indicator of fiscal policy. New Zealand's public finance legislation requires "achieving and maintaining levels of total net worth that provide a buffer against factors that may impact adversely on total net worth in the future" (see New Zealand Treasury, 2005).

${ }^{13}$ For example, Norway's Pension Fund Act defines the objectives of the Government Pension Fund - Global (previously known as the Government Petroleum Fund), which include supporting central government saving to finance the National Insurance Scheme's expenditure on pensions and safeguard long-term interests in using the government's petroleum revenues. The injection of petroleum income into the economy should be in line with the expected real return of the Government Pension Fund, estimated at 4 percent. This guideline implies that the structural non-oil budget deficit should be equal to 4 percent of the assets in the fund at the beginning of the budget year. Anderson et al (2006) provide details.
} 


\section{F. Comprehensiveness of the Fiscal Framework and Institutions to Implement It}

\section{Comprehensiveness}

An FRL-type law, another law, or government regulations should define coverage of both the budget and the annual financial statements. The coverage of the national fiscal framework needs to be comprehensive, covering not only central government inclusive of all off-budget funds, but also all subnational levels of government administration. Although comprehensive coverage of the budget entities whose transactions are included in the MTBF is primordial, in this paper, comprehensiveness is viewed primarily as a characteristic that is related to the success of a FRL once implemented, rather than as a qualifying characteristic. For this reason, comprehensiveness is also treated as an optional component of a FRL.

In fiscal reporting, some countries go beyond "general government” by defining "whole-ofgovernment” to include government-controlled nonfinancial enterprises and/or financial enterprises inclusive of the central bank. Consolidation is helpful for macrofiscal analysis and necessary to reduce “creative accounting”. ${ }^{4}$ Such consolidation does not impinge on the independence of the institutions included in the coverage of the MTBF and/or financial statements or statistical reports.

\section{Institutions to implement FRL-type legislation}

A few FRLs establish a special institution to ensure that the FRL's commitments are complied with. The creation of new institutional arrangements in a FRL is considered to be an optional feature of a FRL.

\section{ASSESSMENT OF COUNTRY EXPERIENCE WITH FISCAL RESPONSIBILITY LAWS}

\section{A. Country Experience}

Only four OECD member countries (of which two are emerging economies) currently have in place a FRL as defined in section II (Figure 1). Amongst the advanced countries, only Australia has had in place a FRL for more than 10 years. In 2004, New Zealand's wellknown FRL was consolidated into a revised and more-comprehensive Public Finance Act. ${ }^{15}$ For these two countries, fiscal transparency and accountability were the major motivations for adopting the FRLs: both laws impose strong fiscal reporting requirements on the

\footnotetext{
${ }^{14}$ Clear accounting regulations for recognition the timing and valuation of government assets and liabilities, are also needed to avoid “creative accounting” - situations where government transactions take place but are excluded from conventional accounts. Creative accounting (Bernoth and Wolff, 2006; Koen, 2005; von Hagen et al, 2006) or unreliable accounts (Balassone et al, 2007; Mora et al, 2007) thwart fiscal transparency.

${ }^{15}$ The Public Finance Act 1989 specified the requirements for accrual budgeting and financial reporting by government departments. The Fiscal Responsibility Act 1994 required accrual-based budget and accounts for the whole-of-government. In 2004, both laws were amended and consolidated in the Public Finance (State Sector Management) Bill. For more details, see New Zealand Treasury (2005).
} 
government. Interestingly, the FRLs in these two countries were adopted a few years after major fiscal consolidation and public management reforms had taken place; they aimed at preventing a reversal of hard-earned improvements in fiscal positions (fiscal surpluses were run in both countries in the 1990s and early 2000s).

Figure 1. Fiscal Responsibility Laws in OECD Countries

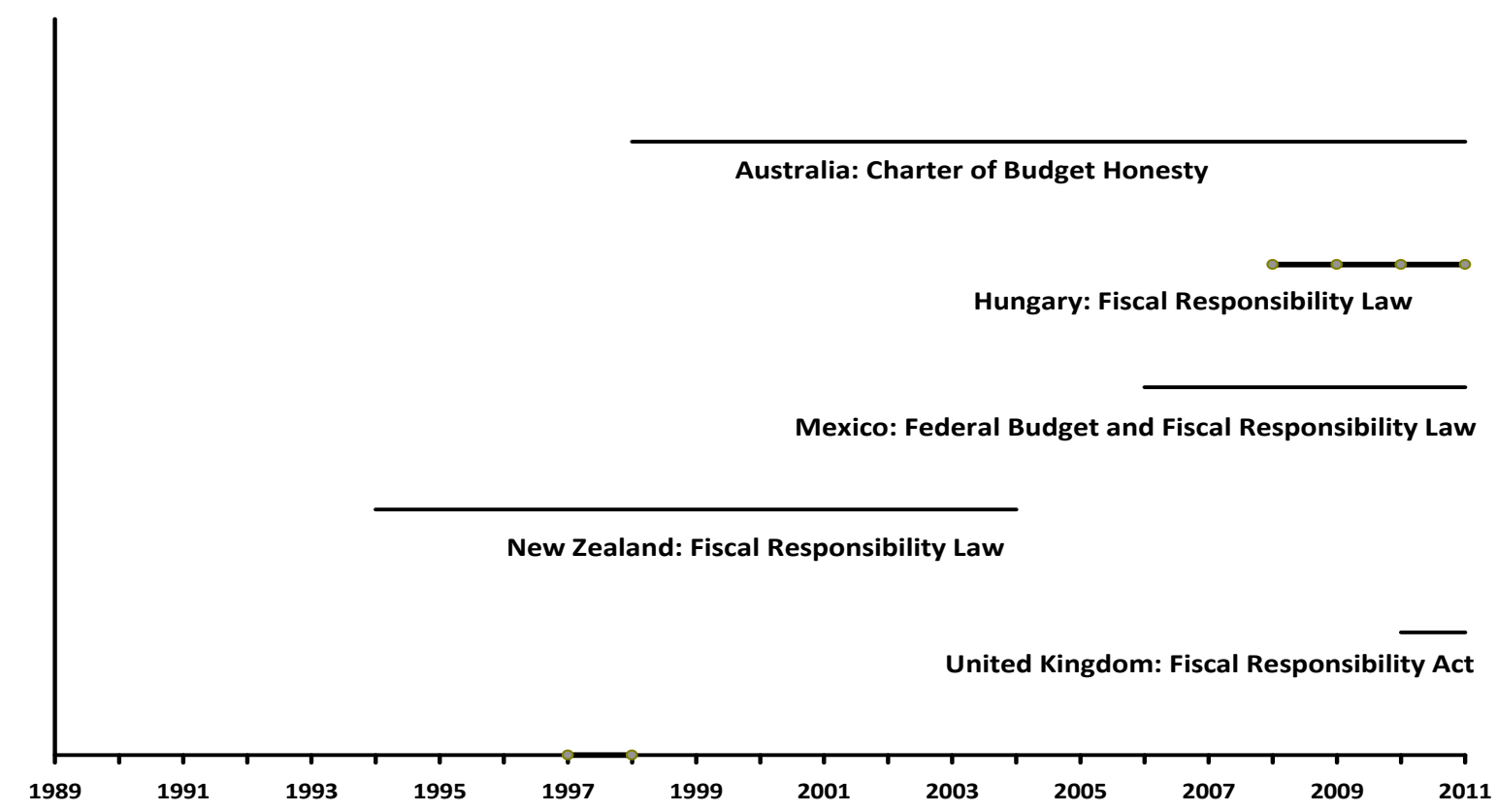

In contrast, limited-life FRL-type laws were adopted in Japan and the United States. ${ }^{16}$ These aimed primarily at fiscal stability concerns, notably to reduce the size of the fiscal deficits prevailing at the time the laws were adopted. Both laws and Hungary's FRL included quantitative fiscal rules - on government deficits, revenues or expenditure. In the case of the United States, the Budget Enforcement Act 1990 came on the heels of the Balanced Budget and Emergency Deficit Control Act of 1985. The United Kingdom's recent FRL focuses on both fiscal transparency and stability: the previous Labor government and the new coalition government are required to announce and adhere to fiscal consolidation plan (Box 1).

\footnotetext{
${ }^{16}$ For Japan's Fiscal Structural Adjustment Law 1997, see Box 2, p. 256, Lienert and Jung (2004), and Appendix II; for the United States Budget Enforcement Act 1990, see Box 2, p. 449, op. cit.
} 


\section{Box 1. United Kingdom: The Fiscal Responsibility Act, 2010}

In February 2010, Parliament adopted the Fiscal Responsibility Act. At the same time, the Treasury made available to Parliament a draft of the revised Code for Fiscal Stability, first prepared in $1998^{17}$ and updated to reflect the provisions in the new Fiscal Responsibility Act.

The Act requires the government to set out at all times a medium-term fiscal consolidation plan (FCP). Parliament is to approve each FCP, which places a binding duty on the government to meet that plan's targets. The Act set out the previous government's FCP, which extended from 2009-10 to 2015-16. In particular, it required the then government to:

- Halve the public sector net borrowing as a share of GDP over four years from its forecast peak in 2009-10. The government set a target in secondary legislation for borrowing to be 5.5 percent of GDP or less in 2013-14;

- Reduce borrowing as a share of GDP in each and every year from 2009-10 to 2015-16;

- Ensure that public sector net debt is falling as a share of GDP in 2015-16.

Such objectives provide a specific focus for Parliament to hold the Government to account for its medium-term fiscal policy. Under the Act, incoming governments are required to prepare FCPs for parliamentary approval.

Source: United Kingdom HM Treasury (2010)

A number of emerging countries, especially in Latin America, have adopted a FRL (Table 1). In these FRLs, the relative emphasis on fiscal stability, not on fiscal transparency and accountability, although in some countries both objectives are included, in comprehensive legislation. For example, Mexico’s 2006 Budget and Fiscal Responsibility Law not only created a balanced budget rule and modified the congressional budget approval process, but also established a formula for calculating oil prices in budget projections and institutionalized stabilization funds, mainly for surplus oil revenues (for details, see Curristine et al, 2009). Many FRLs in Latin America and Asia include numerical fiscal rules.

\footnotetext{
${ }^{17}$ The Code is not a law, since it was not approved in 1998 by all of Parliament's constituent bodies-it was only adopted by resolution in the House of Commons, in accordance with the miscellaneous provisions of the 1998 Finance Act.
} 
Table 1. Fiscal Reponsibility Laws in Emerging and Developing Countries

\begin{tabular}{|c|c|c|c|}
\hline \multicolumn{2}{|c|}{ Principle: } & \multirow{2}{*}{$\begin{array}{l}\text { Fiscal } \\
\text { stability } \\
\text { Numerical } \\
\text { targets? }\end{array}$} & \multirow{2}{*}{$\begin{array}{c}\text { Fiscal transparency and accountability } \\
\text { Publication requirements }\end{array}$} \\
\hline Country & $\begin{array}{l}\text { Year of } \\
\text { Law } 1 /\end{array}$ & & \\
\hline \multicolumn{4}{|c|}{ Latin America } \\
\hline Argentina & 1999 & $\begin{array}{l}\text { Debt, deficit, } \\
\text { spending }\end{array}$ & $\begin{array}{l}\text { Report of budgets for all levels of government, to be published on websites, along with quarterly budget } \\
\text { execution and debt reports. }\end{array}$ \\
\hline Brazil & 2000 & $\begin{array}{l}\text { Debt, } \\
\text { spending }\end{array}$ & $\begin{array}{l}\text { Government must present an account of budget execution every two months, report on budget management } \\
\text { every four months, and identify remedial policies to achieve fiscal targets if needed. }\end{array}$ \\
\hline Colombia & 1997 & $\begin{array}{l}\text { Debt, deficit, } \\
\text { spending }\end{array}$ & $\begin{array}{l}\text { Government must present a medium-term fiscal framework before the budget, stating fiscal objectives and } \\
\text { explanations and deviations from previously set targets. A quasi-fiscal activities report is also required. }\end{array}$ \\
\hline Ecuador & 2002 & Debt/deficit & Government must present a four-year plan with goals and strategies, and report periodically on progress. \\
\hline Panama & 2008 & Debt/deficit & $\begin{array}{l}\text { Government must present a medium-term fiscal framework including tax expenditures, contingent liabilities, } \\
\text { public guarantees and claims in courts. The Social Security Agency must report to the Ministry of Finance } \\
\text { estimates of pension liabilities }\end{array}$ \\
\hline Peru & 1999 & Debt/deficit & $\begin{array}{l}\text { Government must present a macro-fiscal framework, covering three years, containing revenue, expenditure, } \\
\text { public investment, and public debt projections. Reports needes for reevaluations of the framework. }\end{array}$ \\
\hline \multicolumn{4}{|r|}{ 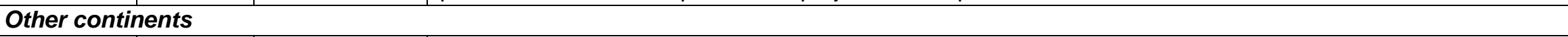 } \\
\hline Hungary & 2007 & $\begin{array}{l}\text { Debt, deficit, } \\
\text { spending }\end{array}$ & $\begin{array}{l}\text { A Fiscal Council prepares macroeconomic forecasts, baseline budget projections, estimates of the fiscal } \\
\text { effects of budget bills, and provides information, upon request, to the President and parliament. }\end{array}$ \\
\hline India & 2003 & Deficit, debt & $\begin{array}{l}\text { Government must present a medium-term fiscal policy statement, a fiscal policy strategy statement, a } \\
\text { macroeconomic framework and quarterly reports on fiscal developments. }\end{array}$ \\
\hline Nigeria & 2007 & $\begin{array}{l}\text { Deficit, debt, } \\
\text { revenue }\end{array}$ & $\begin{array}{l}\text { Federal and State governments must present to Parliaments medium-term macro-fiscal plans, covering four } \\
\text { years, containing fiscal policies, strategic priorities, reference oil price, fiscal risk statement, and budget } \\
\text { execution reports. }\end{array}$ \\
\hline Pakistan & 2005 & Debt, deficit & $\begin{array}{l}\text { Federal government must present to the National Assembly a medium-term budget statement, a fiscal policy } \\
\text { statement, and a debt policy statement, all at specificed dates in the year. }\end{array}$ \\
\hline Sri Lanka & 2003 & Debt/deficit & $\begin{array}{l}\text { Presentation to Parliament of a statement containing four-year fiscal policy goals, short-term objectives, } \\
\text { strategic priorities, and key fiscal measures; a mid-year fiscal update and a final budget outcome report are } \\
\text { also required. }\end{array}$ \\
\hline
\end{tabular}

Sources: Corbacho and Schwartz (2007); country MoF websites.

$1 /$ "Year" indicates the year the law was first adopted. In the countries with numerical fiscal rules in the FRL, the law was frequently amended because targets were not meet and/or dates to achieve them needed to be postponed. 


\section{B. Successes and Failures of FRLs}

In advanced countries, and most developing countries, the fiscal transparency and accountability requirement of FRLs were largely complied with. Following adoption of FRLs, Parliaments and the public have been provided with fuller fiscal information, ranging from medium-term fiscal policy plans and targets through to fuller ex post reports of overall fiscal performance. Accrual accounting reforms, which were introduced before the FRLs in New Zealand and the United Kingdom, contributed to the improvements in the quality and comprehensiveness of fiscal information. New Zealand's 1994 FRL has served as a model for other countries, so it is instructive to summarize its strengths and weaknesses (Box 2) and lessons learnt. Prior to the FRL's adoption, short-term fiscal policy was manipulated to stabilize aggregate demand rather than directing it to long term policy objectives. Such policies were unsuccessful and, at times, pro-cyclical rather than counter cyclical (Scott, 1996). Moreover, the 1984 and 1990 incoming governments faced fiscal situations much worse than was presented pre-election. The FRL successfully tilted the balance of fiscal decision-making away from short-term economic and policy considerations towards strategic and long-term fiscal objectives.

\section{Box 2. New Zealand: Strengths and Weaknesses of the 1994 Fiscal Responsibility}

Act

\section{Strengths}

- The FRL brought a greater focus in annual budgets to issues of fiscal prudence and longer-term fiscal strategy.

- $\quad$ Numerical fiscal rules were not included in the FRL.

- The fiscal consolidation program during 1993 to 2003 was successful in achieving large fiscal surpluses, positive government net worth, major reductions in net public sector indebtedness, and progressively higher ratings for foreign currency debt.l

- The strong fiscal position was achieved despite major change in the electoral system, which resulted in coalition (not single party majority) governments as from 1996.

- Fiscal targets of successive governments were largely achieved thanks to significant reductions in central government current spending, from some 40 percent of GDP in the late 1980s to below 31 percent of GDP by 2001.

\section{Weaknesses}

- $\quad$ Rules that focus on limiting deficits may not discipline spending. For example, governments can use increased revenues from economic growth for spending, buying votes from favored constituencies.

- The law did not impose adequate value-for-money disciplines on new and existing government spending.

Sources: Rae (2002), Scott (1996); Wilkinson (2004). 
Many of the New Zealand's FRL requirements formalized a number of developments that had evolved in previous years, especially on fiscal reporting and transparency (Janssen, 2001). These included the shift to generally accepted (accrual) accounting practice, and the publication of regular short-term fiscal forecasts and a pre-election economic and fiscal update. The law's putative weaknesses are debatable as they mainly concern the type and extent of fiscal rules that could have been included in the FRL. Wilkinson (2005) has suggested that the Act could have been stronger by adding a 'top down' constraint that limited the growth of government spending to population growth plus inflation and required surplus revenue to be returned to taxpayers rather than being spent in constituencies.

The enduring nature of Australia's Charter of Budget Honesty and New Zealand's FRL (although now consolidated in comprehensive public finance legislation) suggests that, to be successful, a FRL should not be too prescriptive, particularly with respect to the fiscal stability and sustainability objectives. In particular, given the widespread failure of experiences of including quantitative fiscal rules in FRLs (section IV F) - or enforcing compliance with supranational fiscal rules in the case of EU countries - it is questionable whether the option of including numerical fiscal rules in FRLs should be pursued.

The achievement of the fiscal stability objectives of FRLs has been mixed. When targets are realistic and there is political willingness and consensus for taking the necessary revenue and/or expenditure measures for achieving them, FRLs have been successful. However, most emerging countries were unsuccessful in meeting the quantitative targets imposed by their FRLs. Several countries (e.g., Argentina, Colombia, Peru) had to amend their FRLs 2-3 years after their initial adoption. Amendments in FRLs usually changed the fiscal targets or pushed back the deadline for attaining the fiscal deficit or debt "rules". A similar lack of success was seen in India and Sri Lanka (for details, see Appendix III). In Latin America, Brazil's FRL (Box 1, IMF, 2001), which has now been in place for a decade, has been largely successful in attaining its main objectives. This is remarkable, given that the law applies not only at federal level but also encompasses all 26 independent States. Prior to adoption of the FRL, Brazil's States had been fiscally irresponsible, especially with respect to borrowing, which had led to a federal bailout of subnational debt (see Box 2, IMF, 2001).

\section{Why Most OECD ANd Advanced Countries Have Not Adopted A FRL}

\section{A. Adequacy of Existing Legal Framework for Budget System}

Several-but not all-OECD and other advanced countries have a strong tradition of embodying in a law the principles that govern the budget system. The Constitution may include articles - or even a chapter (e.g., Germany, Poland) — relating to public finance. Constitutional provisions can include one or more of the three main principles included in a FRL. For example, Germany, Poland and Switzerland have constitutional fiscal stability rules, while other countries have constitutional procedural budget rules (Box 3). 


\section{Box 3. Constitutional Constraints on Budget Management}

France 1/: Limitations on Parliament budget amendment powers. Article 40 of the 1958 Constitution states that bills and amendments introduced by members of Parliament shall not be admissible when their adoption would have as a consequence either a diminution of revenues or the creation or increase of an item of public expenditure.

Germany: Golden rule —now a structural deficit rule. The 1949 Basic Law, as amended in 1968, contained a chapter on public finances, including a "golden rule". In 2009, a new constitutional fiscal rule was adopted; it requires near-balance in the structural federal budget balance, taking into account the effects of cyclical fluctuations on all budgets of the Federation. Exceptions are provided for extreme situations: natural catastrophes and extraordinary emergencies (Appendix IV provides some further details). The Constitution also mandates a Fiscal Stability Council for coordinating intergovernmental fiscal relations.

Poland: Debt rule and limitations on Parliament budget amendment powers. The 1997 Constitution includes the Maastricht Treaty's 60 percent debt/GDP ratio. The national definition of debt is not identical to ESA95 and excludes, for example, the debt of the Road Fund. The Constitution also states that only the government is allowed to increase the level of the deficit, while the Parliament may only modify the composition of revenue and expenditure.

Singapore: Balanced budget fiscal rule. The 1965 Constitution requires the government to have a balanced budget over its term of office. In implementing this rule, a government may only consider as revenue up to half of the annual net investment income from accumulated reserves (including sovereign wealth funds). The Constitution contains an "escape clause" that allows a government to engage in deficit financing and draw on past reserves.

Switzerland. The 1999 Constitution requires the Confederation to "maintain income and expenditure in balance" 2 . A ceiling for total expenditure is approved in the annual budget, based on expected revenues and after taking account of the economic situation. Exceptional circumstances may justify a higher ceiling, decided by the Federal Assembly. If the expenditure ceiling is exceeded, compensation for the additional expenditure must be made in subsequent years (details are regulated by law).

Sources: Constitutions of each country; OECD Journal of Budgeting (various issues).

1/ In May 2010, given its high spending/GDP ratio, France was considering writing into the Constitution a five-year commitment for the path of the structural balance for all general government bodies: central government, social security institutions, and local governments. For details, see www.performancepublique.gouv.fr.

2/ / The constitutional rule means maintaining a structural balance over the cycle. It is supplemented by a "debt brake" rule, introduced by law in 2003 (for more details, see Box 5 of IMF, 2010b). During the recent financial crisis, Swiss general government debt remained stable and is about 30 percentage points below the EU average. 
Italy's 1948 Constitutional budget procedural rules include a rather unusual one, namely that new taxes and new expenditures cannot be introduced in the law approving the budget. ${ }^{\mathbf{1 8}}$ Some Constitutions require a comprehensive law for fiscal management. As examples:

- $\quad$ France's 1958 Constitution requires the conditions for annual budget laws to be laid out in an "organic (budget) law”, which is a higher level law than ordinary laws.

- $\quad$ Germany's Constitution requires a uniform budget system for all levels of government, via a federal law that establishes principles applicable to the Federation and the Länders' budget laws, budget management and long-term financial planning.

- $\quad$ Poland's Constitution requires the principles of and procedures for the preparation of a draft State Budget, the level of detail and the requirements for a draft State Budget, as well as the principles of and procedure for implementation of the Budget, to be specified by statute.

In general, a Constitution elaborates on requirements for the overall budget system, not just the parts of it relating to fiscal stability, transparency and accountability. In view of this, some countries consolidate all budget-related legal provisions in one, or just a few, key laws pertaining to the budget system. In France, for example, nearly all provisions relating to the central government's annual budget system are contained in the 2001 Organic Budget Law. ${ }^{19}$ Similarly, in Germany, the legislatures of the Federation and each of the 16 Länder have adopted a "Budget Principles Law" as required by the Constitution (Appendix IV elaborates further on the legal basis of Germany’s budget system). Poland's 1998 Public Finance Act includes fiscal stability provision and procedures for limiting debt should it rise towards the 60 percent of GDP threshold (Rutkowski, 2007, describes the 50 percent and 55 percent debt thresholds).

Some countries’ FRL-type laws focus on ex post fiscal reporting requirements, without imposing a requirement for short-term fiscal policy-making to be framed in the context of a medium-term fiscal strategy. This is the case when a law is adopted to put in place a new government accounting system, such as the United Kingdom’s Government Resources and Accounts Act 2000 or Iceland’s Government Financial Reporting Act (Box 4).

\footnotetext{
${ }^{18}$ Italy's annual budget is a formal law that reconfirms pre-existing budget-related legislation. For more details on Italy’s constitutional budget provisions, see paragraph 12 of IMF, 2002.

${ }^{19}$ An old law relating to expenditure control, dating from 1922, is also still operative in France. Central government (or "State") budget transactions exclude those of the social security institutions, which are covered by a separate Organic Law adopted in 1996. See pp. 185-218 of Lienert and Jung, (2004) for details.
} 


\section{Box 4. Iceland: Government Financial Reporting Act, No. 88/1997}

Following a review of the government's budgeting and accounting system, important reforms were introduced, applicable as from 1998. Although medium- and long-term fiscal projections are required by the Act, the law did not formalize requirements for forward-looking fiscal policy strategy statements, nor its revisions, such as requiring a six-monthly review of budgetary performance for parliament. The Act focused on ex post reporting and included:

- Budgeting and accounting were put on a modified accrual basis.

- Five groups of public entities were identified for fiscal reporting purposes: central government; government financial institutions, including banks and insurance companies; government nonbank lending agencies; non-financial public enterprises; and companies with government majority ownership.

- Government accounting is to be in line with private sector accounting standards, with the notable exception that central government investment, which is to be reported as expenditure in the year of purchase. The accounting of assets and liabilities was strengthened in the law.

- Financial reporting was brought into line with international accounting standards as regards the definition, classification and presentation of financial information.

Source: Iceland Ministry of Finance website, http://eng.fjarmalaraduneyti.is/legislation/nr/563

\section{B. Law Perceived to be Less Necessary or Unnecessary for FRL}

Some countries may not perceive it to be necessary to legislate that the government prepares a forward-looking fiscal strategy. Although MTBFs are prepared in nearly all OECD countries, only 50 percent of the 30 member countries do so because it is a legal requirement (see OECD 2003 survey of budget practices). Similarly, for ex post accounting of budget outcomes, although a law often requires presentation of annual financial statements to parliament, it is less frequent for a law to require a formal six-monthly review of budget performance. Many advanced countries voluntarily publish monthly/quarterly fiscal outturns on MoF websites in the interests of transparency and availability of fiscal information.

Similarly, for fiscal stability and sustainability purposes, a country may not perceive it to be necessary to adopt a law. In 2010, some advanced countries were beginning to adopt fiscal consolidation measures, following sizeable fiscal stimulus packages. With the prospect of huge future debt burdens (IMF, 2010a), fiscal consolidation was a macro-fiscal necessity. In the Euro-zone countries particularly, the unsustainable medium-term consequences of unchanged fiscal policies and the risk of a currency-zone crisis were strong incentives for some countries to take bold measures to reign in burgeoning fiscal deficits. Neither legislated fiscal rules, nor another FRL-type law, were required to prod countries into fiscal stabilityenhancing actions, even in countries with a strong penchant for using law. 
Prior to the recent financial crisis and widening of fiscal deficits, successful fiscal stabilization policies have taken place without resorting to a FRL-type law. ${ }^{20}$ In general, fiscal consolidation pronouncements are likely to be successful when there is strong political commitment to implementing the policies necessary to achieve fiscal targets, rather than adopting FRL-type laws, including those with fiscal rules. At best, FRLs furnish a preventative fiscal framework rather than acting as devices to enforce fiscal stability.

In some countries, particularly in Scandinavia, there is a relaxed attitude towards using law to regulate the budget system. FRL-type laws are not important for promoting accountability or stability objectives. Denmark and Norway have no specific laws to guide actors operating the national budget system (Lienert and Jung, 2004). In such countries, where legal formalities are not viewed as essential, the objectives of FRLs can be achieved by regulations-issued either by the government (MoF) or by parliament.

\section{Independent Institutions Contribute to the Accountability of Government}

Advanced countries generally have well developed institutions for promoting transparency and accountability, whose independence is assured by laws other than a FRL.

\section{External Audit}

The supreme audit institution (SAI) is a key accountability agency, serving primarily parliament in its aims to hold the executive accountable. A separate (External) Audit Law, elaborating on constitutional provisions, is widespread in advanced countries. ${ }^{21}$ Such laws specify the SAI's attributions, independence and responsibilities. They are clearly not FRLtype laws. However, the transpaency and accountable mandate of a SAI are not only the SAI's raison d'être, but also fully consistent with the essential aims of a FRL. In fact, by auditing annual financial statements of government and, in an increasingly larger number of advanced countries, certifying accounts, detecting shortcomings in transparency and accountability for responsible public financial management, well functioning SAIs lessen the need for the government to be "forced" by law to become more transparent and accountable.

\section{Independent Fiscal Councils}

Some advanced countries have established an independent fiscal council or similar body with oversight powers in the area of fiscal policy. Such councils can defined such as national bodies, coming on top of or besides those involved in routine budgetary processes, which regularly provide independent fiscal policy analysis and/or recommendations (see European Commission, 2006b, which found that 15 of the then 25 EU Member States had a fiscal council of one form or another). The core roles of fiscal councils, which are bodies independent of both the government and parliament, are outlined in Box 5.

\footnotetext{
${ }^{20}$ For country experiences, see Guichard et al (2007) and Wagschal and Wenzelburger (2008).

${ }^{21}$ For the possible contents of such a law, see Table III.5 of Lienert and Jung, 2004.
} 


\section{Box 5. Roles of Independent Fiscal Councils}

- $\quad$ Provide inputs that assist in the proper preparation of the budget (e.g., unbiased macroeconomic and/or budgetary forecasts).

- $\quad$ Conduct analysis of fiscal policy issues such as debt sustainability, prepare alternative estimates of the budgetary impact of policy measures, and assess the impact of any fiscal rules.

- Monitor whether fiscal developments are in line with the main fiscal policy objectives of the government, including numerical fiscal rules.

- $\quad$ Publish reports, with recommendations on appropriate fiscal policies. The objective is to influence the public debate on fiscal policies, and possibly increase the reputational cost for the conduct of unsound policies by the government.

Sources: Debrun and Kumar (2007); Jonung and Larch (2004); Wyplosz (2008).

An independent fiscal council can be created by a dedicated law, a FRL, a broader law, or by regulation. Hungary established such a council in its 2008 FRL (see Hungary Ministry of Finance, 2010). Similarly, Nigeria created an independent Fiscal Responsibility Commission in its 2007 FRL. The United States’ nonpartisan Congressional Budget Office was created in 1974 by a broad law on congressional budget control procedures. ${ }^{22}$ Some fiscal councils have not been created by law. For example, Sweden's government (not parliament) created an independent fiscal council in 2007 (Ljungman, 2007).

Fiscal councils’ roles can substitute for the core transparency and accountability objectives of a FRL. Even if their role is limited to preparing alternative medium-term fiscal projections and non binding comments on the government's fiscal strategy and measures, the existence of an independent fiscal council lessens the need for adoption of a FRL. In the three Westminster countries that have adopted FRLs, it is not surprising that an independent fiscal council does not exist. ${ }^{23}$ In EU countries, there is evidence that fiscal councils have contributed significantly to fiscal discipline and the transparency of fiscal policy (EC, 2006b).

\footnotetext{
${ }^{22}$ See p. 447 of Lienert and Jung, 2004, for the other components of the Congressional Budget Act.

${ }^{23}$ In the 1960s, New Zealand created an independent Monetary and Economic Council, which published reports on the fiscal and economic situation twice a year. The reports provided an alternative voice to that of the dominant Treasury (MoF). The council was abolished about 15 years after its creation - and prior to the adoption of the 1994 FRL whose need would have been lessened if the Council had continued to exist as a body promoting fiscal transparency. In the United Kingdom the National Audit Office audits the key assumptions underlying the government's fiscal projections. However, in 2010, the new coalition government created an independent fiscal council, to provide an independent view on the U.K.'s fiscal consolidation to that of H.M. Treasury.
} 


\section{Supranational Fiscal Rules and Fiscal Stability Laws in EU countries}

Twenty of the 33 advanced countries are European Union (EU) member countries. The euro zone countries are subject to the three fiscal rules of the Stability and Growth Pact (SGP), notably that: the general government fiscal deficit is less than 3 percent of GDP; government (gross) debt is less than 60 percent of GDP; and over the economic cycle, the general government fiscal deficit should be "close to balance or in surplus". To comply, euro zone countries draw up Stability and Convergence Programs (Box 6). These resemble provisions of a FRL.

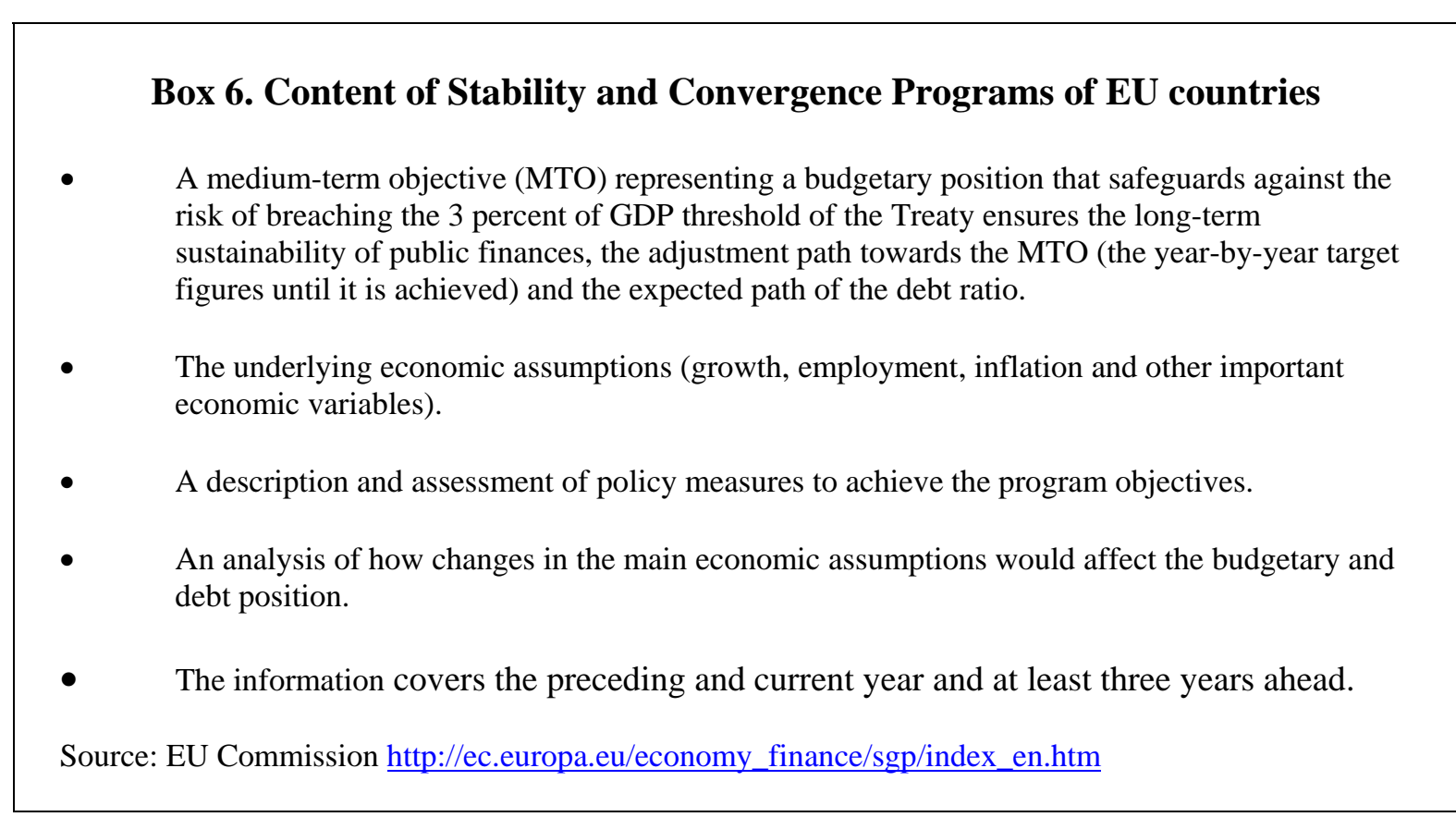

The EU framework obviates the need for an EU member country to adopt a FRL for many aspects of fiscal stability. This does not prevent a country from adopting a FRL for accountability and stability reasons, as the example of Hungary demonstrates. Some other prospective or recent-new EU member countries, notably Latvia, Romania and Serbia, have adopted, or are planning to adopt, an FRL as a means to achieve and/or preserve fiscal stability. ${ }^{24}$

Nonetheless, the EU framework provides an obligation on member countries not only to provide a quantified medium-term budget framework, but also to declare its policy action designed to get back on track should there be slippage relative to the numerical rules. In

\footnotetext{
${ }^{24}$ The Latvian authorities were finalizing a draft fiscal responsibility law in early 2010. The main aims are to anchor fiscal policy on a credible and sustainable path, limit public debt and fiscal deficits, and reduce procyclicality in fiscal policy (Latvia, 2010). A similar situation prevailed in Romania: a draft FRL was submitted to parliament by end-March 2010. These were IMF program structural benchmarks in both countries.
} 
particular, under the "Excessive Deficit Procedure," a country indicates how an excessive fiscal deficit will be reduced. The authorities agree with the EU on annual targets for attaining the SGP's threshold deficit within a specific time frame. In 2009-10, many EU countries were declared to have excessive deficits and most were required to reduce their deficits to 3 percent of GDP by 2012 or $2013 .^{25}$ These procedures are very comparable to those required in some FRLs. For example, Australia's Charter of Budget Honesty requires the government to explain how revised fiscal objectives and strategic priorities relate to the principles of sound fiscal management and how specific temporary fiscal policy actions adopted (or to be taken) for moderating cyclical fluctuations will be reversed.

\section{Fiscal Stability Laws and Domestic Stability Pacts}

Some EU countries have adopted fiscal stability laws in order to apply the EU's comprehensive budget framework, which relates to "general government", i.e., all budget entities and extrabudgetary funds are included. In Spain and Portugal fiscal stability laws were adopted in 2001 to apply the SGP's framework in the context of decentralized fiscal management (Appendix $\mathrm{V}$ provides details). For constitutional reasons relating to autonomous regions, two laws were adopted in each country. More importantly, all four laws were adopted to specify the budget responsibilities of independent entities at all levels of government. In 2006, Spain's law was amended to include rules for a "balanced budget over the cycle”, to align its own legal framework for budget procedures as closely as possible to the SGP's fiscal stability requirements and numerical rules.

Germany also has a fiscal stability law, adopted in 1967—long before the euro-zone was conceived. It reflects Germany's pioneering work on the importance of medium-term budget projections as a tool for planning overall macroeconomic stability. The budget-related legislation of the 1960s was implemented in the heyday of Germany's attachment to Keynesian fiscal policy. This legislation is now largely obsolete (Baumann et al, 2008).

To apply the EU national stability rules, some EU countries have adopted "domestic stability pacts", which aim to allocate the fiscal deficit and debt rules between central (federal) government and local governments. Austria and Italy (Box 7) and Germany (see section 3 of Lübke, 2005) have adopted such pacts. Austria’s pact is the equivalent of law (Blöndal and Bergvall, 2007), whereas this is not the case in Germany, whose domestic stability pact is not legally binding; OECD (2004) considered this to be a shortcoming.

\footnotetext{
${ }^{25}$ For details, see http://ec.europa.eu/economy finance/sgp/deficit/countries/index en.htm.
} 


\section{Box 7. Austria and Italy: National and Domestic Stability Pacts}

\section{Austria}

The 1999 National Stability pact (NSP) is a treaty between the Federation, Länder and municipalities. It set up an enforcement mechanism on how the general government deficit is to be allocated to the different levels of government. The need for such rules arises from the fact that about one third of government expenditure is carried out by subnational governments, over which the federal government has limited control. The NSP was a by-product of regular fiscal discussions between the different levels of government and was ratified by the federal parliament and the nine Länder parliaments. The NSP sets deficit and surplus targets for all three levels of government, which are fixed for a period of 4-5 years. The NSP for 2005-08 envisaged a decline in the general government deficit, to achieve overall balance in 2008. Firm understandings on the contribution of each level of government were included. However, the overall target was not attained. The pact was renegotiated and replaced by the NSP for 2008-13, which is also off-track, not least as a consequence of the financial crisis. The NSP foresees sanctions (ultimately fines) if a government does not fulfill its budget balance objectives.

\section{Italy}

The Domestic Stability Pact (DSP) was first introduced in 1999 in order to involve regions, provinces and municipalities in helping to achieve national fiscal targets. Under the DSP, subnational governments’ fiscal deficits and total expenditures were constrained. Implementation proved problematic for various reasons, including: (i) there were frequent changes in the DSP's targets; (ii) some spending, notably health and investment, was excluded from the DSP's targets; (iii) the DSP became a tool for centralized control of expenditure, even though the decentralization process, subnational governments' tax and spending assignments had not stabilized; and (iv) the DSP budget balances (cash basis) did not correspond to the EU relevant balances. Nonetheless, in the early years after 1999, most regions and local governments respected the DSP. However, in recent years, the growth of spending a subnational level has generally been above target.

These stability laws and pacts address primarily budget comprehensiveness issues. The EU "general government" framework is appropriately wide, covering all central government activities, off-budget social security funds (whose spending can be larger than that of central government spending in some EU countries) and local governments (including spending financed from own revenues). In contrast, several of the well-know FRLs are confined to central government (Brazil is an exception—see Appendix VI).

\section{E. Role Played by Coalition Agreements}

In several European countries and New Zealand, electoral laws include proportional representation elements, which result in a multiplicity of political parties and coalition governments. In order to reach consensus on a government's economic and fiscal policy program, the coalition partners need to reach agreement on the annual and medium-term fiscal objectives to be effective during the life of the government, typically around four years. For budget aggregates, coalition agreements may be specific or vague. In Denmark, Finland 
and the Netherlands, some coalition agreements' fiscal stability components are quite specific (Table 2). For example, Finland's 2007 coalition agreement quantified tax and revenue measures, and reiterated commitment to a system of "top-down" spending limits. ${ }^{26}$ This agreement was more specific than some laws, e.g., Canada’s Spending Control Act, 1992, which was adopted for fiscal stability reasons, especially via expenditure control. ${ }^{27}$

\section{Table 2 Coalition Agreements in Selected European Countries}

\begin{tabular}{|l|c|l|}
\hline Country & $\begin{array}{c}\text { Year of } \\
\text { agreement }\end{array}$ & Fiscal Balance, Debt and/or Spending Objectives \\
\hline $\begin{array}{l}\text { Denmark: A 2015-plan } \\
\text { was endorsed by the } \\
\text { coalition partners in the } \\
\text { Convergence Program }\end{array}$ & 2007 & $\begin{array}{l}\text { Balance: Structural budget surpluses in every year } \\
\text { towards 2015. } \\
\text { Debt: Ensure a stable net debt-to-GDP ratio in the } \\
\text { longer term. }\end{array}$ \\
\hline $\begin{array}{l}\text { Finland: Government } \\
\text { Program of Prime } \\
\text { Minister Matti } \\
\begin{array}{l}\text { Vanhanen's } \\
\text { second Cabinet }\end{array}\end{array} \quad 2007$ & $\begin{array}{l}\text { Balance: a structural surplus of one per cent of GDP to } \\
\text { be achieved by the end of the parliamentary term } \\
\text { (2011); the central government finances will never } \\
\text { show a deficit of more than 21/2 per cent of GDP, even } \\
\text { in a weak economy. } \\
\text { Spending limits. Central government expenditure } \\
\text { by 2011 will at most be Euro 1.3 billion greater than the } \\
\text { spending limits of March 8, 2007. }\end{array}$ \\
\hline $\begin{array}{l}\text { Netherlands: Coalition } \\
\text { partners' policy statement } \\
\text { for 2007-11 }\end{array}$ & 2007 & $\begin{array}{l}\text { Balance: A structural surplus of at least one per cent of } \\
\text { GDP in 2011. } \\
\text { Debt: National debt will drop from around 50 percent } \\
\text { "now", to 40 percent in four years. }\end{array}$ \\
\hline
\end{tabular}

Sources: Denmark: http://uk.fm.dk;

Finland: http://www.valtioneuvosto.fi/hallitus/hallitusohjelma/pdf/en.pdf

Netherlands: http://www.government.nl/Government/Policy statement

In a few advanced countries (e.g., Sweden), where minority governments have proven to be relatively long-lasting (contrary to political theory analysis), debt and fiscal balance objectives of the government are agreed with opposition parties, to ensure successful passage of the annual or medium-term budget appropriations.

\section{F. The Limited Success of Including Quantitative Fiscal Rules in Law}

To address large fiscal deficits and rising public debt, some advanced countries have adopted FRL-type laws that included numerical fiscal targets. It was hoped that the law itself would force policy-makers to reach consensus on the revenue and expenditure policy measures. However, these efforts (as in emerging countries—see section III) have generally not been

\footnotetext{
${ }^{26}$ Ljungman (2008 and 2009) reviews the experiences of top-down budgeting, including in Finland.

${ }^{27}$ Box 2, p. 160 of Lienert and Jung (2004) summarizes Canada’s Spending Control Act 1992.
} 
successful. ${ }^{28}$ The examples of failure to achieve deficit or debt objectives by writing fiscal rules into a law include:

- $\quad$ USA. the Balanced Budget and Emergency Deficit Control Act, 1985 (Box 8)

- Japan. Fiscal Structural Reform Act, 1997 (Appendix II)

- $\quad$ EU countries. Even before the recent crisis, which has led to very large fiscal deficits in some EU countries, the 3 percent of GDP deficit rule and 60 percent of GDP debt rule were frequently flaunted, including by some of the largest EU countries.

- Germany's previous constitutional “golden rule” was breached with little political cost, for two main reasons: (1) enforcement mechanisms were weak: the borrowing rule related to the ex ante budget (which was relatively easy to respect), not the ex post budget outturns (as a result, borrowing took place other for investment, which was not well defined); (2) the rule applied to gross investment, thereby allowing depreciation of capital to be debt-financed and privatization revenues to be spent (OECD, 2008).

\section{Box 8. United States: FRL-type legislation in the 1980s and 1990s}

- The Balanced Budget and Emergency Deficit Control Act of 1985 Act established maximum deficit amounts in dollar terms. If the deficit exceeded the law's statutory limits, the President was required to issue a sequester order that would reduce all non-exempt spending by a uniform percentage. In the event, the limits were breached because Congress had exempted most of the budget from the sequester process and the targets were unrealistic (a sequester order in 1990 would have required a 32 percent reduction in defense programs and a 35 percent reduction in non-defense spending).

- $\quad$ The Budget Enforcement Act (BEA), 1990. This law established statutory caps on discretionary spending and a pay-as-you-go (PAYGO) rule that required tax reductions and increases in entitlement spending to be offset by other tax increases or entitlement cuts. Impelled by strong economic growth and buoyant tax revenues, and with initial success from the BEA's spending limits, the federal fiscal deficit turned to a surplus position in 1998. Subsequently, both major political parties began to abuse the BEA's provisions for "emergency spending” and spending caps were no longer respected. By 2002, following tax cuts and higher defense outlays, the BEA was allowed to expire.

Sources: IMF ( 2003a); http://budget.senate.gov/democratic/commhist.html

\footnotetext{
${ }^{28}$ Even when not embedded in law, rules-based fiscal frameworks were largely suspended during the 2008-09 financial crisis (IMF, 2009).
} 
The failed experiences of laws with numerical targets embedded in them contrasts with the success of FRLs that include only qualitative objectives for key macro-fiscal variable such as debt and the fiscal balance. The latter allow flexibility for a government to change the medium-term trajectory for fiscal balances and debt, provided that the reasons for changes are spelt out.

Brazil's FRL has proved to be enduring in part because it does not establish fixed targets for overall fiscal aggregates, national debt or the consolidated fiscal balance for general government. There are nonetheless some specific fiscal rules (notably for salary spending) and states and municipalities (but not the Federation) have debt limits. The FRL also requires that all governments establish fiscal targets in the annual Budget Guidelines Law (see Appendix VI). The FRL applies to all three levels of government and has contributed to an improvement in the overall fiscal situation, especially at regional and local levels. This is partly due to the FRL's strong enforcement mechanisms, which have resulted in the withholding of federal transfers to noncomplying states and municipalities. Institutional and administrative sanctions are also implemented by the Courts of Accounts (TCU). Some TCU decisions have resulted in fines being paid by officials and a prohibition to run for elections. Ordinary judicial courts can also sanction officials that have committed crimes in relation to the nonobservance of provisions of the FRL, which is supplemented by a "Fiscal Crimes Law.” Such sanctions include imprisonment or impeachment, and some politicians (e.g., mayors) have lost their positions or been excluded from running in elections. The Brazilian example raises the question as to whether a FRL, when accompanied by strong compliance mechanisms that are enforced, can impose fiscal discipline on budget actors.

\section{G. The Political Difficulty of Adopting FRLs}

From the point of view of an economist, the objectives of a FRL-fiscal stability, transparency and accountability_are desirable and uncontroversial. Avoiding excessive government deficits and debt, providing full information on government transactions and asset/liability positions, and ensuring that unelected government officials are held accountable to elected representatives, are all essential for good fiscal management.

From a politician's viewpoint, all three objectives are fully consistent with fundamental democratic values and are likely to be supported. However, there is a proviso: the objectives should not interfere with electoral promises, party policy platforms or constituency concerns. Political actors are likely to support the objectives of fiscal transparency and accountability in most circumstances (one-party States or other non-democratic regimes usually choose to suppress information). In contrast, democracies may not necessarily support fiscal stability objectives. Political debate can become intense when quantitative fiscal rules are proposed as part of a FRL-type law. Some political groupings may be unconcerned by high fiscal deficits and unsustainable public debt, or turn a blind eye to market reactions and risk premia on government bonds. Even if a fiscal deficit or debt crisis is impending, a government or 
parliament may leave their successors to deal with the problem, after upcoming elections. Alternatively, when a draft FRL is proposed, a political stalemate may result, which takes considerable time to resolve (this was the case in Mexico, whose executive and legislature initially had two quite different versions of a draft FRL and considerable time was needed to reach consensus prior to adoption of the FRL in 2006).

\section{Rejection by parliament of a draft FRL}

A country's parliament may not necessarily adopt a draft FRL proposed by the government. This was the case in Korea in 2003 when Parliament considered a draft Fiscal Responsibility Law that consolidated the previously proposed Special Act for Fiscal Soundness and the existing Budget and Accounts Law (Kim, 2003). The draft FRL aimed at strengthening fiscal discipline by requiring a three-year fiscal plan. It also required various fiscal reports to be presented to the National Assembly, as well as tightening the requirements for the adoption of supplementary budgets. However, when the draft FRL was debated in parliament, political parties were unable to reach agreement on the definition of public debt. This concerned particularly the coverage of public debt: the level of total public debt inclusive of the debt and debt guarantees for autonomous government agencies and public enterprises was much higher than core central government debt. The parliamentary impasse resulted in the FRL being abandoned. ${ }^{29}$

\section{H. Strong Legislatures Reject Executive Dominance in Budget Matters}

It is not a coincidence that the parliaments of Australia, New Zealand and the United Kingdom — all of which have adopted FRLs — also have virtually no budget amendment powers (Lienert, 2005; Wehner, 2006). The passage of such a law may prove to be difficult in a country where parliament does not wish to have itself "boxed in" by legislation that restricts its fiscal room to maneuver, especially if the initiative for such legislation comes from a government whose majority in parliament is not assured. It is not surprising that, once the "deficit problem” that plagued the United States' federal authorities in the mid-1980s and early 1990s improved later in the 1990s, the FRL-type legislation was allowed to lapse. In Brazil, compromises were made when the FRL was adopted: the Congress decided not to include in the FRL any debt limits on federal government (footnote 30, Appendix VI).

Sweden is another example of a parliament that is fully involved, on an ongoing basis, in attaining the objectives of the principles of FRLs. Endorsement—or modification—of the government's proposed strategy takes place in the context of a two-stage budget approval

\footnotetext{
${ }^{29}$ However, in 2006 Parliament adopted a comprehensive National Fiscal Act that modernized the budget system. The 2006 law incorporates several of the provisions of 2003 draft FRL, including requiring a mediumterm fiscal framework a performance-based budget system, and new government accounting arrangements.
} 
process by parliament. ${ }^{30}$ However, Sweden has never adopted legislation to force the government to draft a fiscal strategy or prepare reports on fiscal performance. This happens as a matter of course, in part because Sweden has had a long-standing tradition of openness, including in budgetary matters. This contrasts to the Westminster countries where FRLs were initiated by the government and adopted in parliament, with no effective opposition.

\section{Freedom of Information Laws Set Tone for Transparency}

In many advanced countries, there are constitutional guarantees for the right of access to information. These guarantees are enhanced when there is specific legislation to support them. Freedoms of information (FoI) laws establish "right-to-know" procedures for requests from individuals or organizations for government-held information. The burden of proof rests on the government to provide the reasons for not disclosing government information. Nondisclosure is usually limited to issues relating to national security.

Over 85 countries have implemented some form of FoI legislation. Advanced countries dominate. For example, 25 of the 30 OECD member countries (83 percent) have adopted such legislation. In contrast, only 21 percent of the 156 non-OECD IMF member countries have promulgated FoI laws.

When a FoI law is in place, a government is bound to publish and to promote openness. Of course the information requests made under FoI legislation far exceed those relating to fiscal transparency, accountability and stability. However, the mere existence of a FoI law is a sign to society that the country's political authorities are willing to share information on any subject, including those pertaining to the topics covered in FRLs. FoI laws promote the voluntary release of government information. To meet fiscal transparency requirements, including publishing forward-looking information on fiscal developments, a country with a FoI law has less need to adopt a FRL. Further research could test the hypothesis that there is an inverse relationship between the existence of a FoI law and the need for a FRL.

\section{Conclusions}

This paper first defines FRLs-limited-scope public finance laws that focus especially on two objectives: fiscal transparency and accountability of the government to parliament. Although a number of advanced countries have adopted FRL-type laws (which usually include fiscal stability provisions), only two advanced countries currently have in place a narrowly-defined FRL. The various reasons for the apparent lack of necessity, desire or consensus to adopt a FRL are summarized as follows:

\footnotetext{
${ }^{30}$ The State Budget Law 1996 provides the legal basis for this procedure. See p. 365, Lienert and Jung (2004).
} 
- $\quad$ Advanced countries generally have well-established legal frameworks for public financial management. Parliaments have been active in adopting laws for many years, in some cases for centuries. In the past 50 years, there have been few major disruptions such as revolutionary changes in political regimes (ending of one-party states, dictatorial or military regimes). With well-functioning democratic institutions, there has been a long period of "settling down" for the legal frameworks for the budget system.

- In several countries, the Constitution provides articles that impinge directly on the objectives of FRLs, lessening the need for a FRL. In others, the Constitution requires a high-level ("organic") public finance law that provides the framework for the entire budget system, not just FRL-related issues. This does not mean that there is no need to amend existing public finance laws. New Zealand, the country that pioneered a wave of FRL-type legislation as from 1994, amended its Public Finance Act and, at the same time abrogated its FRL in 2004 when it consolidated two separate laws into more comprehensive legislation for budget management.

- $\quad$ Fiscal stability objectives can be achieved by arrangements other than by the adoption of a dedicated FRL. Some countries have adopted binding agreements on political coalition partners; these specify macro-fiscal objectives for the duration of the government. Such agreements contain provisions that overlap with limitedduration FRLs.

- In the EU countries, quantitative targets for debt and fiscal deficits are embedded in the Maastricht criteria and the Stability and Growth Pact. To the extent that compliance mechanisms are enforced, this lessens the need for an EU country to adopt a law for fiscal stability reasons. Nonetheless, some Euro-zone countries have adopted a fiscal stability law. These laws exclude transparency provisions, since some of these are required by the EU in Stability and Convergence Programs. A major challenge currently is to reduce large fiscal deficits and government debt to the levels of the targets of the EU convergence rules. Based on past EU country experiences with compliance with Excessive Deficit Procedures, it is questionable whether embedding fiscal rules in "permanent" directives is effective.

- $\quad$ The experience of embedding numerical fiscal rules-specific debt or deficit targetsin FRL-type legislation has been disappointing. This has been the case in both advanced and emerging countries. Japan and the United States provide examples of FRL-type legislation that was either unsuccessful or not durable.

- $\quad$ Many advanced countries already have in place institutional arrangements for providing fiscal information to the public, obviating a need for a FRL. In most longstanding democracies, governments provide fiscal information to the public-both forward looking budget strategies and reports on recent past fiscal developments. In 
contrast, some lower-income countries have been pressured to adopt FRLs by multilateral agencies.

- $\quad$ Many advanced countries have Freedom of Information Acts, which indicate a willingness to share nearly all government information with the public. Several countries that have recently adopted, or not yet adopted, a FoI Act, have had difficulty in providing reliable fiscal information to the public. Unsatisfactory and creative government accounting does not happen in a vacuum: some countries' governments have not volunteered to commit to full transparency of public finances nor created external audit offices or other independent fiscal agencies that hold the government to account regarding the quality of fiscal information.

- $\quad$ Many advanced countries have a clear separation of executive and legislative powers, with parliaments that are generally effective in holding the government to account. It is not coincidental that Westminster countries-where there is nonseparation of the executive and the legislature, and little effective power of parliament in budgetary matters - are the main ones that have adopted FRLs in advanced and developing countries (this paper examines FRLs in India, Pakistan, and Sri Lanka-countries with Westminster inheritance). To this day, governments of Westminster countries propose tax policy changes and implement them immediately after the budget speech, with only perfunctory parliamentary discussion. On the expenditure side, the very restrictive budget amendment powers of parliament, the limited time in parliament for proposing and discussing alternative spending policies, and the superficial endorsement by parliament of Westminster governments' medium-term budget spending policies thwarts actions by parliamentary committees to hold governments to account. It is therefore gratifying that several governments of Westminster countries volunteered in the 1990s to become more transparent by causing parliament to adopt a FRL.

The above considerations suggest that the possible adoption of a FRL in advanced countries should be viewed with caution. Given the experience of implementing FRLs-especially those that include quantified fiscal rules-achieving the objectives of a FRL would be most effective in countries where there is strong political commitment and enduring institutional arrangements for its implementation, as well as adequate sanctions to ensure compliance. Also, prior to proposing a limited-scope FRL, it would be essential to consider the adequacy of the entire legal framework for budget management. 


\section{Appendix I: Australia's Charter of Budget Honesty, 1998}

The following reports are required by the Act.

\section{1. (Medium-term) Fiscal strategy statement, which includes}

- the government's long-term fiscal objectives within which shorter-term fiscal policy will be framed;

- explains the broad strategic priorities on which the budget is based;

- specifies the key fiscal measures for the budget year and the following three financial years: (i) the government's fiscal objectives and targets; and (ii) the expected outcomes for the specified key fiscal measures;

- explains how the fiscal objectives and strategic priorities specified relate to the principles of sound fiscal management spelt out elsewhere in the Act;

- specifies fiscal policy actions taken or to be taken by the government that are temporary in nature, adopted for the purpose of moderating cyclical fluctuations in economic activity, and indicate the process for their reversal; and

- explains broadly the reporting basis on which government fiscal reports will be prepared.

\section{Annual budget economic and fiscal outlook report, which includes:}

- federal government budget sector and federal general government sector fiscal estimates for the budget year and the following three financial years;

- the economic and other assumptions for the budget year and the following three financial years;

- discussion of the sensitivity of those fiscal estimates to changes in those economic and other assumptions;

- an overview of the estimated tax expenditures for the budget year and the following three financial years;

- a statement of the risks, quantified where feasible, that may have a material effect on the fiscal outlook, including: (i) contingent liabilities; (ii) publicly announced Government commitments that are not yet included in the fiscal estimates; and (iii) government negotiations that have yet to be finalized.

The report:

- takes into account, to the fullest extent possible, all government decisions and all other circumstances that may have a material effect on the outlook.

- is based on external reporting standards, with departures identified in general terms.

- does not have to include information that the Treasurer considers confidential commercial information or where disclosure could prejudice national security

\section{Mid-year economic and fiscal outlook report}

4. Annual Final budget outcome report

5. Other reports

- Intergenerational report

- Preelection economic and fiscal outlook report

- Costing of election commitments

Source: http://www.comlaw.gov.au 


\section{Appendix II: Japan Experiences with Legislated Fiscal Rules}

There are regular exceptions to the "golden rule". The Public Finance Law (1947) stipulates that national expenditure must be financed by revenues other than government bonds or borrowings, i.e., the budget must be balanced. The law sets exceptions: the government can issue bonds or borrow funds for financing public works or other investments. The rationale behind this provision is that public works create assets for the nation that match the government liability incurred by borrowing. After the 1973 oil crisis, the government issued deficit-financing bonds. To do so, a special law was adopted in 1975. Special laws have been enacted every year since (except for 1990-1993). As a result, the stock of debt has sky-rocketed, being composed of both construction and deficit-financing bonds.

\section{Fiscal deficit and spending ceilings were included in the Fiscal Structural Reform Act} (FSRA) enacted in 1997, but targets were missed. The FSRA aimed to: (1) restore the golden rule by FY 2003, by limiting net bond issuance to the level of public investment; and (2) for the national and local governments, reduce the deficit to GDP ratio to below 3 percent by FY 2003; and (3) impose ceilings on most major individual expenditure lines such as social security transfers, spending on public works and education spending. With a recession in 1998, however, it was clear that the targets had become unrealistic and it was decided to suspend the FSRA in December 1998. In the event, the targets were missed by wide margins.

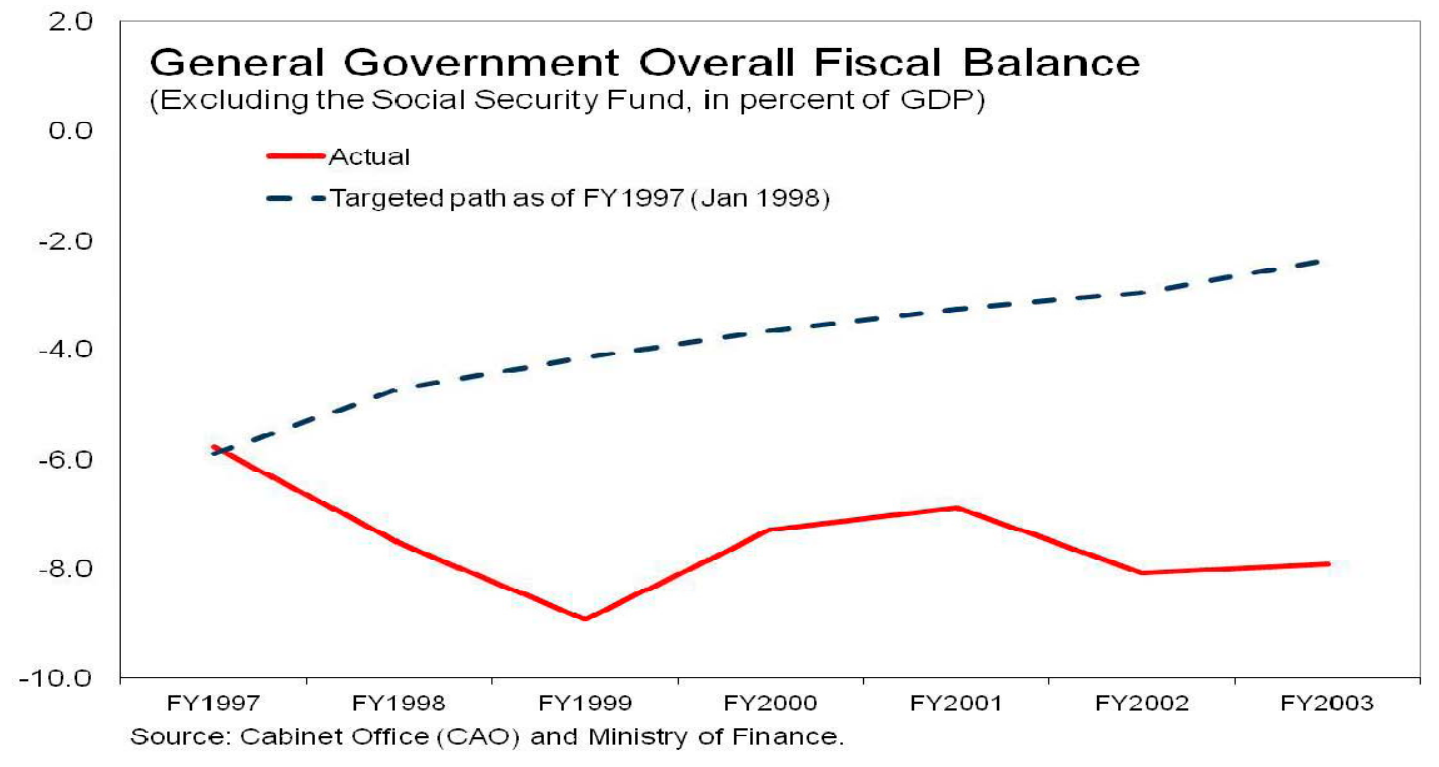

The experience of FSRA contains the following lessons. First, it appears unwise to legislate expenditure ceilings during an economic downturn. Second, any cap on categories of expenditure should target not only the initial budget but also the final budget (the FSRA capped only the initial budget, whereas expenditure increased significantly through the adoption of supplementary budgets).

Sources: Tanaka, 2003; Lienert and Jung (2004) pp. 258; Miyazaki (2006) 


\section{Appendix III: Experiences of FRLs in India, Pakistan and Sri Lanka}

\section{India}

The Fiscal Responsibility and Budget Management Act (FRBMA) was enacted in 2003. Its goal was to restore fiscal sustainability, following over a decade of large fiscal deficits. The FRBMA incorporated numerical fiscal rules, provisions for improving fiscal transparency and monitoring, and bringing medium-term considerations into budget formulation.

The FRBMA applies to the national government only, although many States of India have also adopted FRLs. It emphasizes transparency by requiring that the government presents to both houses of parliament a medium-term fiscal policy statement; an annual fiscal policy strategy statement; a macroeconomic framework statement; and quarterly reports on fiscal developments. A key requirement was elimination of the central government recurrent deficit, by March 2008. This deadline was postponed. The law also established caps on government guarantees and total liabilities, and prohibited borrowing by the government from the Reserve Bank after April 2006.

India's experience with fiscal rules has been mixed. The FRBMA contributed by strengthening procedural rules underpinning the fiscal framework. While a substantial fiscal consolidation initially occurred following adoption of the FRBMA, this was partly due to robust economic growth and tax administration reforms. Despite the fiscal consolidation, offbudget activities increased, deadlines to comply with the fiscal target were extended, and fiscal adjustment was not underpinned by expenditure rationalization. Significant slippages with respect to the 2008/09 fiscal deficit targets were expected even before the global crisis and fiscal stimulus, raising questions about the effectiveness of the FRBMA as a disciplining tool. Also, by establishing targets on the recurrent balance (not the overall balance), the FRBMA provides incentives for creative accounting. Finally, the law relies only on reputational sanctions for noncompliance, which may be too weak to ensure enforcement.

\section{Pakistan}

Pakistan's Fiscal Responsibility and Debt Limitation Act (FRDLA) was approved in June 2005. The law aims to eliminate revenue deficits and reduce public debt to prudent levels by, inter alia, following the principles of effective public debt management.

Like in India, the FRDLA contains both procedural rules and numerical targets that apply solely to the federal government. Procedural rules include the presentation and publication of an annual medium-term budgetary statement; a fiscal policy statement; and a debt policy statement. These documents contain multiyear projections of key fiscal and macroeconomic indicators, a description of fiscal policies and objectives, an analysis of fiscal risks, and an evaluation of compliance with fiscal targets. Numerical rules include: (i) lowering public debt to 60 percent of GDP by 2013; (ii) reducing public debt by at least 21/2 percent of GDP each year; (iii) eliminating recurrent deficits by June 2008; and (iv) limiting new government 
guarantees to 2 percent of GDP. Fiscal rules can be suspended if social and poverty-reducing expenditures fall under $4 \frac{1}{2}$ percent of GDP, or health and education spending fail to double as a percent of GDP in a 10 year period. Escape clauses comprise national security emergencies and natural calamities, to be declared by the National Assembly.

If the federal government fails to meet the debt reduction target, it must take measures to return to the debt reduction path within two years. These constraints cannot be applied to social and poverty reduction expenditures, or to expenditures specified in the Constitution. The FRDLA also mandates the establishment of a debt policy coordination office.

Pakistan's experience with FRDLA has been reasonable. The public debt target was achieved ahead of schedule. However, the recurrent deficit target was breached by 1.7 percent of GDP in 2009 (although it was reduced from 3.3 percent in 2008); and new government guarantees (2.1 percent of GDP) were slightly above target. The fiscal policy statement and debt policy statement — both available on the Ministry of Finance's website-provide a clear view of performance targets. However, the lack of intra-year reporting on fiscal outcomes and incomplete government coverage in the FRDLA is a source of concern.

\section{Sri Lanka}

Sri Lanka adopted the Fiscal Management Responsibility Act (FMRA) in 2003, following a long history of fiscal imbalances that led to a crisis in 2001, with the central government debt-to-GDP ratio exceeding 100 percent. The FMRA attempts to address several fiscal shortcomings, including the lack of codified rules for the formulation and execution of the annual budget. Also, it aims to strengthen transparency requirements and places the budget within medium-term considerations.

Sri Lanka's FMRA sets numerical targets for the medium-term applicable to the central government only. It also caps government guarantees. The FMRA originally required the central government's overall deficit not to exceed 5 percent of GDP by 2006, but the government economic statement to parliament accompanying the 2005 budget already announced that such target would not be met before 2008 .

Sri Lanka's experience with FMRA has been poor. The date to achieve the overall fiscal deficit target of 5 percent of GDP was first modified in 2005, and repeatedly postponed thereafter. This has diminished the credibility of the FMRA. In addition, significant quasifiscal activities by commercial public corporations and other off-budget activities, which are only partially monitored and have intensified in recent periods, do not bode well for fiscal responsibility. The FMRA relies solely on reputational sanctions, which have proven to be ineffective, especially given the country's long history of noncompliance with budget targets. Finally, the FMRA's escape clauses are loosely defined.

Sources: Simone and Topalova, 2009; http://www.finance.gov.pk/finance_publications.aspx 


\section{Appendix IV: Germany: Legal Basis for Budget System}

Germany has a comprehensive and detailed legal framework for budget processes. The Basic Law or Constitution, lays out the fiscal responsibilities of the Federation and the Länder. It establishes that the Federation and the Länder independently prepare, adopt and execute their own budgets. In 2009, a new constitutional fiscal rule was adopted (see Box 3 and below). The Constitution is supplemented by various laws, mostly adopted during the late 1960s.

A distinguishing feature of Germany's legal framework is the Law on Budgetary Principles (Haushaltsgrundsätzgesetz - HGrG), which is applicable to the Federation, each of the independent provinces (Länder) and all local governments (municipalities). The HGrG lays out obligations for budget preparation and execution, government accounting and external audit. The Federation and each of the 16 Land have adopted budget principles laws; all 17 laws are based on the common framework of the HGrG.

The Constitution mandates the adoption of a federal law, applicable to both the Federation and the Länder, to govern budget management, including multi-annual financial planning. The 1967 Law to Promote Economic Stability and requires the formulation of five-year plans and promotes responsible fiscal management for both the federal and Länder governments. This law aimed to take the burden of policy adjustment off monetary policy and to make fiscal policy more fast-acting. This 1967 law contains some fiscal stability provisions-one element of a FRL. Also, the HGrG and the federal and Länder budget principles laws lay out major fiscal transparency and accountability provisions.

To ensure intergovernmental coordination, the HGrG established a coordinating body, the Financial Planning Council comprising the federal Ministers of Finance and of Economics, the Länder Ministers of Finance, and four representatives of municipalities designated by the Bundesrat at the suggestion of local government associations. A principal aim of this Council is to prepare medium-term budget and financial plans and to set priorities for nationwide fiscal policies. Under the HGrG, all levels of government are obliged to provide the Financial Planning Council with all necessary information. Decisions of the Financial Planning Council are politically binding, but not legally binding.

Under the new constitutional fiscal rule, the maximum permissible net borrowing will be calculated by adding the structural component (limited to 0.35 percent of GDP deficit for the federal government from 2016 and zero deficit for the Lander from 2020), the balance on financial transactions, the cyclical component and, when appropriate, an adjustment for the obligation to reduce debits of the control account The new fiscal rule may require an updating of the public finance laws of the 1960s, as would adoption of a performance-based budget system

Sources: Lienert and Jung (2004), Germany Country Note; Lübke (2005); Ministry of Finance http://www.bundesfinanzministerium.de/DE/BMF_Startseite/node.html? _nnn=true, notably Germany’s Stability Programme, January 2010 update. 


\section{Appendix V: Fiscal Stability Laws in Spain and Portugal}

\section{Spain}

The General Act on Budgetary Stability (GABS) 18/2001 provides principles for implementing the EU's SGP. The law applies to budget entities at all levels of government: central, regional and local. In view of extensive decentralization of fiscal management and to ensure coverage of self-governing communities, a second law (the Organic Act Supplementary to the General Act on Budgetary Stability 5/2001) was adopted.

The budget stability objectives are qualitative-there are no numerical targets in the law, whose budget principles included: stability, multiyear, transparency and efficiency in the allocation and use of public resources. The law requires:

- $\quad$ Budgetary stability. This requires achieving a balanced or surplus budget situation (as defined in the European System for National Accounts). In the first four months of each year, the government, following a joint proposal by the Ministries of Economy and of Finance, is required to establish budget stability objectives for the three next fiscal years, for submission to Parliament. The legislature subsequently approves the aggregate MTBF, which is the reference for the budgets of all general government budget entities. To guide decision-makers, the law requires multiyear scenarios for revenues and expenditure, detailing for each year the expenditure commitments of each budget policy. There is to be top-down ceiling on total expenditure of the national budget. The law also provides for correction of a budget deficit situation and budgetary contingency funds for emergencies.

- $\quad$ Accountability. The law requires the General Comptroller of the State Administration, through the Ministry of Finance, to submit a report on the degree of compliance with the budgetary stability objective in the past year.

- $\quad$ Transparency requires the budgets and accounts of entities included within the scope of the law to include sufficient and adequate information to allow for verification of compliance with the budgetary stability principle.

In 2006, the GASB was amended to introduce fiscal balance targets over the cycle for general government. The fiscal targets vary for "high" growth (budget surpluses), "normal" and "low" growth (small fiscal deficits). A separate target was established for the social security system to ensure its sustainability. The low-growth deficit (up to 1 percent of GDP) was allocated predominantly ( 0.75 percent of GDP) to regional governments. There were no "rules" for allocating high-growth surpluses. Targets for each region were to be determined by bilateral negotiations. The law excluded capital (and some other) expenditure aimed at improving productivity and competitiveness, in an amount up to 0.5 percent of GDP.

Sources: Ley General de Estabilidad Presupuestaria 18/2001, December 12, 2001 (available on website of Spain's Ministry of Economy and Finance); Box 7 of IMF (2005); Box 4 of IMF (2006); Ballart and Zapico (2009); 


\section{Portugal}

The 2001 Budget Framework Law sets out general and common principles for the budget framework and accounts of general government. It also establishes procedures for elaboration, presentation, discussion, parliamentary voting, alterations, and execution of the annual state budget law and it establishes rules on the organization, structure, presentation, and parliamentary voting of the final accounts of the central government. It includes:

- $\quad$ A requirement that annual budgets be elaborated in the context of a multiyear macroeconomic and financial planning framework geared toward maintaining fiscal sustainability.

- A definition of the state budget that includes the budgets of all state services, inclusive of the social security system. It does not include the budgets of the autonomous regions, the local governments, or state enterprises.

- $\quad$ A specification of the state budget cycle: the government has to submit to parliament by October 15 the draft budget for the upcoming fiscal year; a vote on the budget is to occur within 45 days, and the state budget has to be published by end-February.

- $\quad$ During the first two weeks of May of each year, the government has to initiate in parliament a debate on budget execution, and submit to parliament a report that allows evaluating new expenditure policy measures.

- $\quad$ A shift toward activity-based budgeting for the state budget, which is to be based on specific programs, measures, projects, or actions.

- A requirement to implement strengthened reporting and audit mechanisms. The government has until June 30 to present to the National Assembly the accounts of the state for the previous year. The National Assembly then has until December 31 to approve or reject the accounts.

The 2002 Budgetary Stability Law (BSL) is an organic law that defines further the principle of budget stability. It aims at strengthening coordination between different parts of the general government. Public administration bodies are subject to three main principles:

- Budget stability, defined as a budget that is balanced or in surplus (based on the ESA95 definition);

- $\quad$ Reciprocal solidarity. All parts of the general government are to contribute proportionally to achieve budget stability. The BSL stipulates that the state budget may set specific limits to the net increase in indebtedness of various entities of the administrative public sector. Transfers may be reduced proportionately to any excesses over the established ceilings.

- $\quad$ Budget transparency, which requires information disclosure of public entities. Sanctions for non-disclosure may result in budget transfers being suspended.

The BSL also alters the management regime of the autonomous funds and services that, in 2000 and 2001, did not generate at least two-thirds of their expenditures from own revenues. Such entities were incorporated into the state budget.

Sources: Box 2 of IMF, 2003b; Cunha and Braz (2006). 


\section{Appendix VI: Brazil—Features of Legal Framework, including the FRL}

The Federal Constitution, 1988: Requires the preparation, at all levels of governments, of three budget laws - a multiyear plan law (Plano Plurianual - PPA), annual budget guidelines law (Lei de Diretrizes Orçamentárias - LDO) and annual budget law (Lei Orçamentária Anual - LOA). The Constitution also includes a "golden rule"-borrowing should not exceed capital expenditures.

Fiscal Responsibility Law (FRL), 2000. The FRL followed the renegotiation of State debts by the federal government. Key features are:

- Maximum limits on the level of debt of federal, state and municipal governments to be established by the Senate. ${ }^{31}$

- $\quad$ Maximum limits on personnel expenditure, as a proportion of net current revenues. These are specified for each of the three levels of the federation (federal: 50 percent, states: 60 percent and municipalities: 60 percent) and include both active and retired public servants.

- $\quad$ Any new medium-term expenditure has to be "affordable”. In some cases, it is sufficient to show that new expenditure will fit within the established budget expansion baseline (i.e. room created by GDP growth keeping constant policies). For new mandatory expenditure, the requirement is strengthened by the rule that the room has to be created by reducing other expenditure or introducing new taxes. Similar rules also bind any new tax expenditures and subsidies to the private sector.

- $\quad$ Extensive provisions for the monitoring and reporting of budget implementation (2-monthly, 4-monthly, annual).

- $\quad$ Corrective measures to be taken in case of any breaches, including institutional and personal sanctions (additional fines and incarceration for the officials responsible are covered in a separate Fiscal Crimes Law 2000).

Annual Budget Guidelines Laws (LDOs). Each year's LDO must indicate the fiscal targets for the reference year and projections for the two following years, for the overall and primary fiscal balances, the stock of net public debt, total revenues and expenditures, and spending program priorities. The FRL also requires the LDO to provide budget execution information for the preceding two fiscal years, based on which compliance with the fiscal targets is assessed. All targets and outcomes are shown in the Fiscal Targets Annex. The LDO also includes discussion of the impact on revenues and on the net debt-to-GDP ratio of changes in macroeconomic assumptions in a Fiscal Risks Annex. The LDO bill must be submitted to Congress by April 15 of each year; Congress must approve it by June 30. The detailed budget (LOA bill) must be submitted to Congress by August 31, which approves it by December 15.

Sources: IMF (2001); Tollini (2009).

\footnotetext{
${ }^{31}$ The Senate has approved limits for States (twice its annual net current revenue) and for municipalities (1.2 times its annual net current revenue). For the federal government, it has not set any limits since the approval of the FRL in 2000 (in the draft FRL, a limit of 3 times annual net current revenue was proposed by the government, but this was removed in the final FRL adopted by Congress).
} 


\section{BIBLIOGRAPHY}

Anderson, B. and J.J. Minarik, 2006, “Design Choices for Fiscal Policy Rules,” Paper for OECD Working Party for Senior Budget Officials GOV/PGC/SBO (2006), 4.

— Budgeting, Vol. 6. No. 1.

— and James Sheppard, 2009, "Fiscal Futures, Institutional Budget Reform and their Effects: What Can be Learned?”, OECD Journal of Budgeting, Vol. 9. No. 3.

Ayuso-i-Casals, J., Hernandez, D. G., Moulin, L. and Turrini A., 2006, "Beyond the SGPFeatures and Effects of EU National-Level Fiscal Rules,” Prepared for the Workshop Organized by the European Commission on "The Role of National Fiscal Rules and Institutions in Shaping Budgetary Outcomes” (Brussels, 24 November 2006).

Ballart, Xavier and Eduardo Zapico, 2010, Budget reforms in Spain, published in John Wanna, Lotte Jensen and Jouke de Vries, The Reality of Budget Reform: Counting the Consequences in 11 Advanced Democracies (London: Elgar).

Balassone, Fabrizio, Daniele Franco and Stefania Zotteri, 2007, “The reliability of EMU fiscal indicators: Risks and safeguards”, Bank of Italy discussion paper (Temi di discussione del Servizio Studi), Number 633, June.

Baumann, Elike, Elmar Donnebrink and Christian Kastrop, 2008, A Concept for a New Budget Rule for Germany, CESifo Forum 2/2008 (Munich: Ifo Institute for Economic Research).

Baunsgaard, Thomas, 2003, Fiscal Policy in Nigeria: Any Role for Rules? IMF Working Paper No. 03/155 (Washington: International Monetary Fund).

Bernoth, Kerstin and Guntram B. Wolff, 2006, "Fool the Markets? Creative Accounting, Fiscal Transparency and Sovereign Risk Premia”, Deutche Bundesbank Discussion Paper No. 19/2006.

Blöndal Jón R. and Daniel Bergval, 2007, Budgeting in Austria, OECD Journal of Budgeting, Vol. 7. No. 3 (Paris: Organization for Economic Cooperation and Development).

Canada, 2010, “Budget 2010: Leading the Way on Jobs and Growth”, http://www.budget.gc.ca/2010/plan/toc-tdm-eng.html (Ottawa: Department of Finance)

Cebotari, Aliona, 2008, “Contingent Liabilities: Issues and Practice,” IMF Working Paper 08/245 (Washington: International Monetary Fund). 
et al., 2009, "Fiscal Risks: Sources, Disclosure, and Management,” Fiscal Affairs Department (Washington: International Monetary Fund).

Corbacho, A. and G. Schwartz (2007), “Fiscal Responsibility Laws”, in: Ter-Minassian, T. and M. S. Kumar (eds.) Promoting Fiscal Discipline, pp. 58-77 (Washington, DC: International Monetary Fund).

Cunha, Jorge C. and Cláudia R. Braz, 2006, "Public Expenditure and Fiscal Consolidation in Portugal”, OECD Journal on Budgeting, Vol. 6. No. 4 (Paris: OECD).

Curristine, T., E. Aldunate, R. Emery, P. Krause, and A. Redonda, 2009, "Budgeting in Mexico”, OECD Journal on Budgeting, Volume 2009, Supplement 1, (Paris: OECD).

Debrun, X. and M. S. Kumar, 2007, "Fiscal Rules, Fiscal Councils and All That: Commitment Devices, Signaling Tools or Smokescreens?” in: Banca d'Italia (eds.) Fiscal Policy: Current Issues and Challenges, Papers presented at the Banca d'Italia workshop held in Perugia, 29-31

Debrun, X., L. Moulin, A. Turrini, J. Ayuso-i-Casals and M. S. Kumar, 2008, “Tied to the Mast? National Fiscal Rules in the European Union,” Economic Policy, April 2008, pp. 299-362.

Deroose, S., Moulin, L. and Wierts, P., 2006, "National Expenditure Rules and Expenditure Outcomes: Empirical Evidence for EU Member States,” Wirtschaftspolitische Blaetter, 1/2006, pp. 27-42.

European Commission, 2006a, Public Finance Report in EMU—2006. Part III: National Numerical Fiscal Rules and Institutions for Sound Public Finances, European Economy No. 3/2006, (Brussels: European Commission). , 2006b, Public Finance Report in EMU -2006. Part IV: National Independent Institutions, European Economy No. 3/2006, (Brussels: European Commission). , 2009, Public Finance Report in EMU—2009, European Economy No. 5/2009 (Brussels: European Commission).

Everaert, Gretje, Manal Fouad, Edouard Martin and Ricardo Velloso, 2009, "Disclosing Fiscal Risk in the Post-Crisis World," IMF Staff Position Note SPN09/18 (Washington: IMF).

Gleich, Holger, 2003, "Budget Institutions and Fiscal Performance in Central and Eastern European Countries,” European Central Bank Working Paper No. 215.

Guichard, Stephanie; Mike Kennedy; Echkard Wurzel and Christophe Andre, 2007, "What Promotes Fiscal Consolidation: OECD Country Experience,” OECD Economic Department Working Paper No. 553, (Paris: OECD). 
Hallerberg, Mark, Rolf Strauch and Jürgen von Hagen, 2004, “The Design of Fiscal Rules and Forms of Governance in European Union Countries,” European Central Bank Working Paper No. 419.

Hungary Ministry of Finance, 2010, Outline of the Fiscal Responsibility Act and Fiscal Responsibility Act, available on http://www1.pm.gov.hu/web/home.nsf/frames/english

IMF, 2001, Brazil: Report on the Observance of Standards and Codes-Fiscal Transparency Module, IMF Country Report No. 01/217.

— , 2002, Italy: Report on the Observance of Standards and Codes—Fiscal Transparency Module, IMF Country Report No. 02/231

— 2003a, United States: Report on the Observance of Standards and Codes—Fiscal Transparency Module, IMF Country Report No. 03/243

— 2003b, Portugal: Report on the Observance of Standards and Codes—Fiscal Transparency Module, IMF Country Report No. 03/373

— 2005, Spain: Report on the Observance of Standards and Codes—Fiscal Transparency Module, IMF Country Report No. 05/58

—_ 2006, Spain: 2006 Article IV Consultation Report, IMF Country Report No. 06/211

—_, 2007, Manual of Fiscal Transparency (revised), (Washington D.C.: International Monetary Fund).

_ _ 2009, Fiscal Rules: Anchoring Expectations for Sustainable Public Finances, Fiscal Affairs Department, http://www.imf.org/external/np/pp/eng/2009/121609.pdf

—_ 2010a, "Navigating the Fiscal Challenges Ahead”, IMF Fiscal Monitor Series, May, http://www.imf.org/external/pubs/ft/fm/2010/fm1001.pdf

— 2010b, Switzerland: 2010 Article IV Consultation Report, IMF Country Report No. 10/140, http://www.imf.org/external/pubs/ft/scr/2010/cr10140.pdf

Janssen, John, 2001, “New Zealand's Fiscal Policy Framework: Experience and Evolution,” Treasury Working Paper 1/25, http://www.treasury.govt.nz/publications/researchpolicy/wp/2001/01-25/twp01-25.pdf

Jonung, Lars and Martin Larch, 2004, "Improving Fiscal Policy in the EU: The Case for Independent Forecasts,” European Economy Economic Papers No. 201, (Brussels: European Commission).

Kim, Daehaeng and Mika Saito, 2009, “A Rule-Based Medium-Term Fiscal Policy Framework for Tanzania,” IMF Working Paper 09/244. 
Kim, Hyun E., 2003, "Institutional Development in the Korea Financial Sector Accompanying Globalization, and Its Economic Effect”, Institute for Monetary and Economic Research, Bank of Korea.

Koen, Vincent and P. van den Noord, 2005, "Fiscal Gimmickry in Europe: One-Off Measures and Creative Accounting,” OECD Economics Department Working Paper 2005(4).

Kopits, G. and S. Symansky, 1998, Fiscal Rules, IMF Occasional Paper 162, (Washington D.C.: International Monetary Fund).

Kopits, G., 2001, “Fiscal Rules: Useful Policy Framework or Unnecessary Ornament?” IMF Working Paper 01/145.

(ed.) (2004), Rules-Based Fiscal Policy in Emerging Markets, (Palgrave)

Latvia, Republic of , 2010, Second Review and Financing Assurances Review Under the Stand-By Arrangement, IMF Country Report No. 10/65

http://www.fm.gov.lv/?eng/ministry/letter_of_intent (Riga: Ministry of Finance).

Lienert, Ian and Moo-Kyung Jung, 2004, “The Legal Framework for Budget Systems—An International Comparison,” OECD Journal of Budgeting, Vol. 4, No. 3.

_ 2005 , “Who Controls the Budget: The Legislature or the Executive?” IMF Working Paper WP/05/115.

— , and Israel Fainboim, 2010, Reforming Budget System Laws, Technical Notes and Manuals, TNM/10/01 (Washington D.C.: International Monetary Fund).

Ljungman, Gösta, 2007, “Sweden’s New Fiscal Council - Helping assure credible fiscal policy”, blog posting of October 12, 2007, http://blogpfm.imf.org/pfmblog/2007/10/swedens-new-fis.html

—_, 2008, “Expenditure Ceilings_A Survey”, IMF Working Paper WP/08/282.

_ 2009, “Top-Down Budgeting-An Instrument to Strengthen Budget Management,” IMF Working Paper WP/09/243.

Lübke, Astrid, 2005, “Fiscal Discipline between Levels of Government in Germany”, OECD Journal of Budgeting, Vol. 5, No. 2 (Paris: OECD).

Miyazaki, Masato 2006, "Framework for Fiscal Consolidation: Successes and Failures in Japan“, OECD Journal of Budgeting, Vol. 6 No. 4 (Paris: OECD).

Mora , Luis Gordo and Joao Nogueira Martins, 2007, "How Reliable are the Statistics for the Stability and Growth Pact?” European Economy Economic Papers No. 273. 
New Zealand Treasury, 2005, A Guide to the Public Finance Act, August 2005, http://www.treasury.govt.nz/publications/guidance/publicfinance/pfaguide/11.htm\#_toc Fiscal_Responsibility

OECD, 2003, Budget Practices Survey, http://ocde.neverso.com

_ 2 2004, Germany: Linking Fiscal Consolidation to Public Sector Reform, OECD Economic Surveys, Vol. 2004, No. 12, pp. 58 - 96

—_, 2007, Budget Practices Survey, http://webnet4.oecd.org/budgeting/Budgeting.aspx

_ , 2008, Germany: OECD Economic Surveys, Vol. 2007/8, April, pp. 53

Oliva, Carlos, 2001, “Fiscal Responsibility Laws: How Broad Should They Be?”, paper presented at a seminar on fiscal transparency and responsibility, Brazil, November.

Rae, David, 2002, 'Next Steps for Public Spending in New Zealand: The Pursuit of Effectiveness', Economics Department Working Paper No 337 (Paris: Organization for Economic Cooperation and Development).

Rutkowski, Aleksander, 2007, Ceilings and anchors: fiscal rules for Poland, ECFIN Country Focus, Volume 4, Issue 4, Directorate-General for Economic and Financial Affairs, European Union, http://ec.europa.eu/economy_finance/publications/country_focus/2007/index_en.htm

Schick, A., 1996, The Spirit of Reform: Managing the New Zealand State Sector in a Time of Change, Report Prepared for the State Services Commission and The Treasury (Wellington: New Zealand State Services Commission).

_ 2003, "The Role of Fiscal Rules in Budgeting”, OECD Journal of Budgeting, Vol. 3, No. 3, pp. 7-35 (Paris: OECD).

Schuknecht, Ludger, 2004, "EU Fiscal Rules: Issues and Lessons from Political Economy,” European Central Bank Working Paper, No. 421.

Scott, Graham C., 1996, “Government Reform in New Zealand, IMF Occasional Paper No. 140, (Washington D.C.: IMF).

Simone, Alejandro Sergio and Petia Topalova, 2009, “India’s Experience with Fiscal Rules: An Evaluation and The Way Forward, IMF Working Paper WP/09/179.

Tanaka, Hideaki, 2003, "Fiscal Consolidation and Medium-term Fiscal Planning in Japan”, OECD Journal on Budgeting, Vol. 3, No. 2, OECD, Paris, pp. 105-137.

Tollini, Helio, 2009, "Reforming the Budget Formulation Process in the Brazilian Congress", OECD Journal of Budgeting, Volume 2009/1 (Paris: OECD) . 
United Kingdom HM Treasury, 2010, The Fiscal Responsibility Act, http://www.hmtreasury.gov.uk/fiscal_responsibility_bill.htm

von Hagen, Jürgen, 2005, “Fiscal Rules and Fiscal Performance in the EU and Japan,” CEPR Discussion Paper No. 5330. and Guntram B. Wolff, 2006, "What do Deficits Tell Us About Debt? Empirical Evidence on Creative Accounting with Fiscal Rules in the EU,” GESY Discussion Paper No. 148, (Frankfurt: University of Mannheim).

Wagschal, Uwe and Georg Wenzelburger, 2008, "Successful Fiscal Consolidation: An International Comparison”, with other authors (Gutersloh: Verlkag BertelsmannStiftung)

Webb, Steven B., 2004, “Fiscal Responsibility Laws for Subnational Discipline: The Latin American Experience, World Bank Policy Research Working Paper No. 3309 (Washington DC: World Bank).

Wehner, Joachim, 2006, “Assessing the Power of the Purse: An Index of Legislative Budget Institutions,” Political Studies, Vol. 54, No. 4, pp. 767-785.

Wilkinson, Bryce, 2004, "Restraining Leviathan: A Review of the Fiscal Responsibility Act 1994,” New Zealand Business Round Table, www.nzbr.org.nz

Wyplosz, Charles, 2008, “Fiscal policy councils: Unlovable or just unloved?”, Swedish Economic Policy Review 15, pp.11-30.

Yläoutinen, Sami, 2004, "Fiscal Frameworks in the Central and Eastern European Countries, Ministry of Finance, Finland, Discussion Paper No. 72. 